\title{
Assessment of Sectoral Greenhouse Gas Emission Reduction Potentials for 2030
}

\author{
Kornelis Blok ${ }^{1, *(\mathbb{D}}$, Angélica Afanador ${ }^{2}$, Irina van der Hoorn ${ }^{3}$, Tom Berg ${ }^{3}$, \\ Oreane Y. Edelenbosch ${ }^{4,5}$ and Detlef P. van Vuuren ${ }^{5,6}$ \\ 1 Faculty of Technology, Policy and Management, Delft University of Technology, Jaffalaan 5, 2628 BX Delft, \\ The Netherlands \\ 2 Navigant, a Guidehouse Company, Am Wassermann 36, 50829 Cologne, Germany; \\ angelica.afanador@navigant.com \\ 3 Navigant, a Guidehouse Company, Stadsplateau 15, 3521 AZ Utrecht, The Netherlands; \\ irina.van.der.hoorn@navigant.com (I.v.d.H.); tom.berg@navigant.com (T.B.) \\ 4 Present affiliation: Department of Management and Economics, Politecnico di Milan, I Via Lambruschini 4/B, \\ 20156 Milan, Italy; oreane.edelenbosch@polimi.it \\ 5 PBL Netherlands Environmental Assessment Agency, Bezuidenhoutseweg 30, 2594 AV The Hague, \\ The Netherlands; Detlef.vanVuuren@pbl.nl \\ 6 Copernicus Institute of Sustainable Development, Utrecht University, Princetonlaan 8a, 3584 CB Utrecht, \\ The Netherlands \\ * Correspondence: k.blok@tudelft.nl
}

Received: 20 January 2020; Accepted: 18 February 2020; Published: 20 February 2020

\begin{abstract}
The aim of this article is to provide an overview of greenhouse gas emission reduction potentials for 2030 based on the assessment of detailed sectoral studies. The overview updates a previous assessment that dates back more than ten years. We find a total emission reduction potential of 30-36 $\mathrm{GtCO}_{2} \mathrm{e}$ compared to a current-policies baseline of $61 \mathrm{GtCO}_{2} \mathrm{e}$. The energy production and conversion sector is responsible for about one third of this potential and the agriculture, buildings, forestry, industry, and transport sectors all contribute substantially to the total potential. The potential for 2030 is enough to bridge the gap towards emissions pathways that are compatible with a maximum global temperature rise of $1.5-2{ }^{\circ} \mathrm{C}$ compared to preindustrial levels.
\end{abstract}

Keywords: emission reduction potential; emissions gap; energy production and conversion; sectoral analysis; bottom-up analysis

\section{Introduction}

As part of the Paris Agreement process, an overwhelming majority of countries have submitted Nationally Determined Contributions (NDCs) setting out their commitments with respect to the reduction of domestic greenhouse gas emissions. Most of these NDCs take 2030 as a target year. The total commitments falls short of being compatible with a long-term target of limiting global temperature rise to levels well below $2{ }^{\circ} \mathrm{C}$ compared to preindustrial levels [1-3]. In the coming year, the governments will be invited to put forward more ambitious commitments, but what is possible? An important question is what the total emission reduction potential is for the year 2030. This article intends to show to what extent the portfolio of technologies and options that are available can provide for a sufficient reduction of global greenhouse gas emissions to be in line with the Paris Agreement.

Various methods exist to provide policy makers with information on climate change mitigation options. Scenarios that are supported by integrated assessment models (IAMs) provide information on comprehensive strategies and account for the interactions between sectors. They can also provide insight into the required level of reduction per sector to reach specific climate goals; see, e.g., Reference [4]. 
However, in general, the technical details of these assessments are relatively low, and in correspondence with their scope and focus, most recent technological developments might be underrepresented [5]. In contrast, studies that start with the (technology) options per sector can typically provide more detail in terms of emission reduction options-these are often referred to as bottom-up studies. They provide a more disaggregated characterization and analysis but are generally less concerned with systemic effects [6]. Such sectoral studies can provide, at a fairly detailed level, how much emission reduction is feasible within certain sectors or for specific emission categories. Ideally, these sectoral emission reduction potentials present the mitigation options in a transparent way and provide a good indication of the areas where climate mitigation action can be achieved. In the past, several studies have looked at the strengths and weaknesses of these methods and at how they can be used together [7].

However, the most recent assessments of (bottom-up) sectoral emission reduction potentials date back more than eight years ago. These include the ones done for 2020 [8,9] and for 2030 by the Intergovernmental Panel on Climate Change (IPCC) [10] and by McKinsey [11] (for a critical assessment of the latter, see Reference [12]). More recent assessments were made by IPCC [13] and the International Energy Agency (IEA) [14], but both did not make a sector-by-sector assessment of the full emission reduction potentials. In addition, several emission reduction potential assessments have been done for specific regions, e.g., for the EU [15], for the US [16], and for 15 developing countries [17]. Also, for specific sectors, assessments have been carried out, e.g., for the Chinese cement industry [18], for shipping [19], and for specific regional categories [20]. Therefore, the emission reduction potential assessments that are available for 2030 either are partial or date back nearly a decade. Since then, climate policy ambitions have been formulated more clearly at the global level in the Paris Agreement as well as at the national level. At the same time, greenhouse gas emissions (GHG) levels have continued to increase and technology development continues [21], making the earlier emission reduction potential assessments obsolete. There is thus an urgent need to fill this knowledge gap and to provide an update on these studies. The aim of this article is to provide new sectoral GHG reduction potentials for 2030 for all sectors at the global level. The focus will be on the socioeconomic potential.

In this article, we estimate the sectoral reduction potential by combining estimates of the impact of specific measures while accounting for their overlap. Based on a literature review, the potential of available measures in all sectors contributing to GHG emissions, including the agriculture and forestry sector, the energy demand sectors, and the energy production and conversion sector, is estimated. This enables us to estimate the total emission reduction potential at the global level. We present a comparison of this information with the emission reduction pathways generated through integrated assessment models (IAMs). While the IAMs have become more and more detailed over time and often contain many bottom-up elements, the outcomes between the two approaches can still differ [7] and contrasting the two approaches provides additional insights.

After describing the methods in Section 2, the assessment of emission reduction potentials on a sector-by-sector basis is presented in Section 3. Section 4 provides an overview and discussion of the results, including a comparison with earlier estimates of the 2030 emission reduction potential, and compares the findings concerning the sectoral emission reduction potentials with the outcomes of the emission reductions calculated with integrated assessment models. The final section summarizes the main conclusions.

\section{Methods}

\subsection{Overall Method Used to Calculate Potential}

Sectoral-based assessments can be used to assess different types of potential. The technical potential refers to the emission reduction that can be achieved by implementing the full set of available options in a given future year. The socioeconomic potential is that part of the technical potential which is economically attractive from a social cost perspective [22]. In this article, we specify the socioeconomic potential as the collection of all emission reduction options that can be achieved at 
a marginal cost of no more than USD100/tCO $\mathrm{CO}_{2} \mathrm{e}$, at current prices (not taking into account benefits other than saved energy costs). This level is similar to the cutoff level that was used in the 4th assessment report of the IPCC [10]. This was the previous global assessment of this type, and using the same cutoff level makes comparisons easier. It is also the carbon price level that is found to be necessary by 2030 to achieve the ambitious reduction pathways that are more or less consistent with the objectives formulated in the Paris Agreement [13,23].

The focus is on six key sectors: agriculture, buildings, energy production and conversion, forestry, industry, and transport. Waste-related options and carbon removal options not connected to a specific sector are discussed in the final subsection of Section 3. The following gases are included in the analysis: carbon dioxide $\left(\mathrm{CO}_{2}\right)$, methane $\left(\mathrm{CH}_{4}\right)$, nitrous oxide $\left(\mathrm{N}_{2} \mathrm{O}\right)$, perfluorocarbons (PFCs), hydrofluorocarbons (HFCs), and sulphur hexafluoride $\left(\mathrm{SF}_{6}\right)$. The assessment is done for the world as a whole. We included all emission mitigation options as they are discussed in the literature and assessed, for example, in the sectoral chapters 7 through 11 of the last contribution of Working Group III to the IPCC (2014) assessment report. Some mitigation categories have not been included as no global quantification is available yet (see the Discussion section). Our approach is in line with the approach followed in the Fourth Assessment Report of the IPCC [10]. First of all, for each sector, an overview is made of (most recent) available literature on emission reduction potentials in 2030. Next, four elements need to be considered: (i) comparability: the studies need to have determined the potentials in ways that lead to comparable results; (ii) coverage: all sectors and all major mitigation categories per sector need to be covered; (iii) baselines: the emission reduction potentials need to be referring to a coherent set of baselines; and (iv) aggregation: mitigation potentials influence each other, even cross-sectorally-this needs to be taken into account in the aggregation process [10]. There will be remaining uncertainties, but these are brought back to the levels that are indicated by the uncertainty ranges. We constrained the sample of abatement measures to those that could be realised through technologies that are available by 2030. There are important uncertainties related to assumptions regarding technology development and implementation rates, for example, how rapidly solar photovoltaic energy production can be scaled up and the rate at which buildings can be retrofitted. Most of the underlying analyses introduces some degree of "realism" in the assessment and its respective assumptions. In general, it is assumed in the following that the potentials can be achieved if countries around the globe are willing to set policies that enable the implementation of the available solutions.

We distinguish two types of potentials. First of all, the "basic potential" includes the categories for which a long history of potential estimates is available. Next, some new categories are included for which only recently the first global estimates of emission reduction potentials were made. These are indicated as the "additional potential". The potentials are calculated with reference to a current policy scenario. Such a scenario is needed to estimate future activity levels and to exclude measures that are already implemented on the basis of such scenario. The main baseline scenario used here is the IEA World Energy Outlook [23]; for more details, see Section 2.2. In case the baseline emissions from our literature sources deviated from the baseline emissions in WEO-2016, we corrected for the difference, e.g., by proportionally scaling up or down the potential. In cases where potentials were given in terms of avoided fossil energy use, we calculated the emission reduction potentials based on average emission factors for 2030 from the World Energy Outlook. For the electricity sector, however, we use the average emission intensity of fossil-fuel-based power plants, as these are the emissions that are commonly avoided when emission reduction measures are taken [24]. The reasoning behind this is that the plants with the highest marginal operating costs are those that are last in merit order. In general fossil-fuel-fired plants have the highest marginal costs; therefore, in case of more energy efficiency improvement or more renewables application, those plants are the first to reduce their output, which justifies our choice. Of course, there is some remaining uncertainty as the fuel mix avoided is not known, but at a global level, this uncertainty will be limited. The average emission intensity for fossil-fuel-based power plants in 2030 is calculated to be $758 \mathrm{~kg} \mathrm{CO}_{2} / \mathrm{MWh}$ in the baseline scenario. In some cases, a switch of energy carriers may occur, for example, from fuel to electricity (e.g., electric 
cars and heat pumps for buildings). In these cases, the potential was corrected for the additional emissions associated with the additional electricity production, in line with the underlying sources.

For several sectors, there is potential overlap between the measures within the sector. In general, if in a sector two mitigation options are available that apply to the same emission category, the first one measure is applied and then the emission reduction fraction of the second measure is applied to the remaining emissions. For each sector, we discuss how we dealt with these overlaps at the end of the respective subsection in Section 3. The most important intersectoral overlap is between the power sector and other sectors. Here, we took a (potentially too conservative) estimate based on the maximum potential that we found in a bottom-up analysis for the power sector.

For each emission category, we calculated the uncertainty of the size of the emission reduction potentials. In some cases, the estimates we found in the literature were single-point potentials; in other cases, the estimates were given in ranges. To ensure consistency and to reflect the uncertainty of the size of the potentials, we applied a general $\pm 25 \%$ uncertainty range to individual abatement categories, which is in line with the uncertainty range that we find for those categories for which an uncertainty range is given. For some measures, we applied a $\pm 50 \%$ uncertainty range in order to stay on the conservative side. We applied the latter to seven abatement measures out of 39 in total: peatland degradation and peat fires, biochar, shifting dietary patterns, decreasing food loss and waste, the various energy efficiency categories, and enhanced weathering measures. Most of these are mitigation options that have a relatively small track record in estimation of the size of the potential and which are therefore inherently more uncertain. We also had to include the energy efficiency measures in this category, as we found out that these estimates showed some uncertainties, e.g., in some cases, they were based on extrapolation. Next, the estimates of energy efficiency potentials always have to be determined as the additional energy efficiency improvement compared to a significant autonomous development. This latter idea introduces additional uncertainty. For the calculation of the uncertainty in sectoral aggregates and in the total, we applied the standard rules for error propagation [25].

\subsection{Baseline Emissions}

We use the Current Policies Scenario of the International Energy Agency's World Energy Outlook [23] as the baseline scenario. This scenario assumes no changes in policies from mid-2016 onwards. In this article, we present for illustration purposes the degree of energy efficiency improvement for all energy efficiency measures. We do this on the one hand compared to the baseline and on the other hand compared to the so-called frozen efficiency level. The calculate the latter, we assume that, in the Current Policies Scenario, the autonomous energy efficiency improvement rate is $1 \%$ per year, which is in line with historic developments [26].

For $\mathrm{CO}_{2}$ emissions from the calcination process in cement manufacturing, we used production data from Reference [14] and the emission factor for process emissions in cement [27].

Few recent baseline projections for the global forestry sector are published. These come with a considerable amount of uncertainty since forests are vulnerable to climate change, even under low-warming scenarios [28]. We use emissions and absorption data from Reference [29].

Emissions from peatland degradation and peat fires are often not included in climate models. No baseline projections for peatland degradation are available. Taking into account trends in i) an increasing area of drained peatland, ii) a decreasing area of already drained peatland, and iii) a decreasing area of drained peatland, we assume they will remain at the current level [30]. Given the increased awareness on the adverse effects of peat fires, we estimate that current emissions based on an extrapolation from Reference [31] will be halved [32].

For non- $\mathrm{CO}_{2} \mathrm{GHGs}$, we use baseline trajectories estimated by the United States Environmental Protection Agency (USEPA) [33], unless more recent global baseline estimates were available. For energy sector, methane emissions were taken from Reference [34] and was updated to become compatible with WEO-2016 [35]. Emissions originating from fluorinated gases (HFCs, PFCs, and $\mathrm{SF}_{6}$ ) were taken from Reference [36]. 
For a detailed sectoral breakdown in the current policy projection, see Table 1 . The total emissions projected for 2030 amount to $61.1 \mathrm{GtCO}_{2} \mathrm{e}$.

Table 1. Emissions by sector in the current policy scenario $\left(\mathrm{GtCO}_{2} \mathrm{e}\right)$ : The emissions related to electricity production are also allocated to the end-use sectors, so these are listed twice in this table. These allocated emissions are given in grey italics and not counted in the total.

\begin{tabular}{|c|c|c|c|c|}
\hline Sector & Category & Gases & $\begin{array}{l}2030 \text { Emissions } \\
\quad\left(\mathrm{GtCO}_{2} \mathrm{e}\right)\end{array}$ & $\begin{array}{l}\text { Sector Aggregates } \\
\text { (GtCO2e) }\end{array}$ \\
\hline \multirow{7}{*}{ Agriculture } & Agricultural soils & $\mathrm{N}_{2} \mathrm{O}$ & 2.48 & \multirow{7}{*}{8.8} \\
\hline & Enteric fermentation & $\mathrm{CH}_{4}$ & 2.35 & \\
\hline & Manure & $\mathrm{CH}_{4}, \mathrm{~N}_{2} \mathrm{O}$ & 0.38 & \\
\hline & Rice cultivation & $\mathrm{CH}_{4}, \mathrm{~N}_{2} \mathrm{O}$ & 0.51 & \\
\hline & $\begin{array}{l}\text { Other agricultural sources (includes burning } \\
\text { of savannahs and from forest clearing and } \\
\text { agricultural residues) }\end{array}$ & $\mathrm{CH}_{4}, \mathrm{~N}_{2} \mathrm{O}$ & 1.18 & \\
\hline & Peatland degradation & $\mathrm{CO}_{2}$ & 1.6 & \\
\hline & Peat fires & $\mathrm{CO}_{2}, \mathrm{CH}_{4}$ & 0.3 & \\
\hline \multirow{2}{*}{ Buildings } & Fuel use (direct emissions) & $\mathrm{CO}_{2}$ & 3.7 & \multirow{2}{*}{3.7} \\
\hline & Electricity use (indirect emissions) & $\mathrm{CO}_{2}$ & 8.89 & \\
\hline \multirow{4}{*}{$\begin{array}{l}\text { Energy } \\
\text { production and } \\
\text { conversion }\end{array}$} & Electricity production & $\mathrm{CO}_{2}$ & 16.31 & \multirow{4}{*}{21.3} \\
\hline & Other energy conversion & $\mathrm{CO}_{2}$ & 1.85 & \\
\hline & Natural gas and oil systems & $\mathrm{CH}_{4}$ & 2.38 & \\
\hline & Coal mining & $\mathrm{CH}_{4}$ & 0.73 & \\
\hline \multirow{3}{*}{ Forestry } & Deforestation & $\mathrm{CO}_{2}$ & 3.44 & \multirow{3}{*}{3.5} \\
\hline & Afforestation and forest management & $\mathrm{CO}_{2}$ & -0.88 & \\
\hline & Other land-use change & $\mathrm{CO}_{2}$ & 0.93 & \\
\hline \multirow{7}{*}{$\begin{array}{l}\text { Manufacturing } \\
\text { Industry }\end{array}$} & Fuel use (direct emissions) & $\mathrm{CO}_{2}$ & 7.31 & \multirow{7}{*}{12.7} \\
\hline & Electricity use (indirect emissions) & $\mathrm{CO}_{2}$ & 6.58 & \\
\hline & Process emissions for cement production & $\mathrm{CO}_{2}$ & 2.3 & \\
\hline & $\begin{array}{l}\text { Emissions from stationary and mobile } \\
\text { combustion }\end{array}$ & $\mathrm{CH}_{4}, \mathrm{~N}_{2} \mathrm{O}$ & 0.77 & \\
\hline & Substitutes for ozone-depleting substances & HFCs & 1.6 & \\
\hline & Hydrochlorofluorocarbon-22 production & HFC-23 & 0.2 & \\
\hline & Other industrial sources & $\begin{array}{l}\text { All } \\
\text { non- } \mathrm{CO}_{2}\end{array}$ & 0.5 & \\
\hline \multirow{2}{*}{ Transport } & Fuel use (direct emissions) & $\mathrm{CO}_{2}$ & 9.42 & \multirow{2}{*}{9.4} \\
\hline & Electricity use (indirect emissions) & $\mathrm{CO}_{2}$ & 0.28 & \\
\hline \multirow{4}{*}{ Other } & Other sectors electricity use (indirect emissions) & $\mathrm{CO}_{2}$ & 0.56 & \multirow{4}{*}{1.7} \\
\hline & Landfilling of solid waste & $\mathrm{CH}_{4}$ & 0.96 & \\
\hline & Other waste sources & $\mathrm{CH}_{4}, \mathrm{~N}_{2} \mathrm{O}$ & 0.03 & \\
\hline & Wastewater & $\mathrm{CH}_{4}, \mathrm{~N}_{2} \mathrm{O}$ & 0.71 & \\
\hline Total & & & & 1.1 \\
\hline
\end{tabular}

${ }^{1}$ Includes emissions due to electricity use in end-use equipment.

\section{Emission Reduction Potential for $\mathbf{2 0 3 0}$ per Sector}

\subsection{Agriculture}

In this subsection, we will first discuss options for the various agricultural production categories. Next, we will also discuss demand-side options. 
For croplands, Smith et al. [37] cite a 2030 mitigation and sequestration potential of $0.74 \mathrm{GtCO}_{2} \mathrm{e}$ in 2030 with $90 \%$ of the potential coming from $\mathrm{CO}_{2}$. The non- $\mathrm{CO}_{2}$ component is more or less in line with the $0.04 \mathrm{GtCO}_{2} \mathrm{e}$ from USEPA [38], presenting a range of options to reduce the emissions originating from crop farming. The mitigation and sequestration can be established through a combination of 1 ) no-tillage and residue management, 2) agronomy, and 3) nutrient management, which are all assumed to be applied on one-third of global croplands. Recently, there has been discussion on no-tillage measures, for example, by Dimassi et al. [39], who argue that an increase in the soil carbon stock may be the result of a redistribution of carbon between soil layers. However, this would not affect the potential from Reference [37], since the area to which no-tillage measures are applied can be substituted with measures that have a more or less similar potential from the other cropland management categories, like agronomy and nutrient management. We therefore maintain the estimated potential of 0.74 $\mathrm{GtCO}_{2} \mathrm{e}$ in 2030 for cropland management.

Grazing lands are typically managed less intensively than croplands, leaving significant potential for enhanced removals and emission reduction. Suggested grazing land measures by Smith et al. [37] include adjusting grazing intensity and allowing for more biomass growth; increasing land productivity by reducing nutrient deficiencies; using more precise nutrient additions, and thus, saving in fertilizer; managing fire (reducing frequency and fire intensity in fire-prone areas); and introducing species, e.g., grass species with higher productivity from associated $\mathrm{N}$ inputs. They have estimated the impacts of these measures by combining emission reduction effects per area from a large database of experiments with the area in various climate zones. Together, these measures have the potential to sequester 0.75 $\mathrm{GtCO}_{2}$ in 2030.

Degraded peatlands drained for agricultural use disproportionally contribute to global GHG emissions from the land-use sectors [40]. When peatlands are drained, organic matter in soils starts oxidising and releases significant volumes of carbon emissions until drainage is reversed or all peat is lost [40]. Smith et al. [37] provides 2030 mitigation potentials for the restoration of cultivated organic (peaty) soils of $1.3 \mathrm{GtCO}_{2} \mathrm{e}$. Emissions from peatland fires can be nearly fully prevented cost-effectively, partly by the same measures and partly by additional fire control measures [41,42], leading to an emission reduction of $0.3 \mathrm{GtCO}_{2} \mathrm{e}$.

Based on a simulation of alternative rice management scenarios using varying management techniques, USEPA [38] estimates an emissions reduction potential of $0.18 \mathrm{GtCO}_{2} \mathrm{e}$ in 2030. The options include measures such as adjusting the flooding regime, applying no-tillage, and using various fertilizer alternatives.

Although current policy emissions from enteric fermentation and manure management make up a significant part of total agriculture emissions, the mitigation potential from livestock management so far is limited. USEPA [38] estimates a global mitigation potential of $0.23 \mathrm{GtCO}_{2} \mathrm{e}$ at costs below USD $100 / \mathrm{tCO}_{2}$ in 2030. The mitigation options with the highest cost-effective potentials are waste and manure digesters, antimethanogens, intensive grazing, improved feed conversion, and propionate precursors (animal feed additions that convert more of the produced hydrogen into propionate instead of methane).

Based on a combination of intensive restoration projects on agricultural lands (15 million ha) and farmer-managed natural regeneration projects ( 135 million ha), the Global Commission on the Economy and Climate estimates that an emission reduction of $1.1 \mathrm{GtCO}_{2} \mathrm{e}$ can be achieved by 2030 [43]. These estimates are scaled up from case-study results in China and Niger. We therefore apply an uncertainty range of $0.5-1.7 \mathrm{GtCO}_{2} \mathrm{e}$.

Recently, biochar has gained attention as a potential carbon removal option for agricultural lands, mainly cropland. Biochar is produced by heating biomass under anaerobic conditions, which under the right conditions can enhance soil fertility and improve soil's water retention properties while enhancing the soil organic carbon content. Using a mix of dedicated crops, residues, manure, and other agricultural inputs, Woolf et al. [44] estimate that a maximum of $1.8 \mathrm{GtCO}_{2}$ e per year can be mitigated over the course of a century. Pratt and Moran [45] arrive at a similar potential. However, biochar 
production will ultimately be limited by the rate at which biomass can be extracted and pyrolyzed sustainably. Under their "maximum sustainable technical potential" scenario, Woolf et al. estimate that, by 2030, a reduction of about $0.2 \mathrm{GtCO}_{2}$ e per year can be realized [44].

We now come to the emission reduction options related to the demand side of the food system. Efforts can be made to lower the carbon footprint of the average diet. Stehfest et al. [46] model the impact of shifting food patterns to a diet recommended by the World Health Organization - which sets recommendations on the consumption of animal products and fat-and compare this effect in two different economic models: IMPACT from the International Food Policy Research Institute and LEITAP from the Global Trade Analysis Project. Both were coupled to the integrated assessment model IMAGE. As a result of less agricultural demand, total GHG emissions decrease by 0.37 to $1.37 \mathrm{GtCO}_{2} \mathrm{e}$ in 2030 in LEITAP and IMPACT, respectively [46].

Stehfest et al. [46] also studied the effect of reducing food waste, utilising the same methods as described in the previous paragraph. Within the agricultural supply chain, significant losses can be identified when considering factors such as harvesting inefficiency, bad harvesting conditions, deterioration during storage, or consumer behaviour. Estimates of total losses vary considerably, between $30-50 \%[47,48]$, and the effect of waste reduction is modelled as a 15 percent reduction in the amount of food needed to meet similar nutrition levels, which requires a $45-75 \%$ reduction of the wasted amount of food. Modelled impacts on GHG emissions range from $0.97 \mathrm{GtCO}_{2} \mathrm{e}$ to $2.0 \mathrm{GtCO}_{2} \mathrm{e}$.

Combining the potentials of all the measures discussed leads to a potential of $3 \mathrm{GtCO}_{2} \mathrm{e}$ in 2030 (uncertainty range 2.3-3.7 $\mathrm{GtCO}_{2} \mathrm{e}$ ) if we exclude the "additional" measures like biochar, peat-related emission reductions, and the demand-side measures. The latter measures add up to a $3.7 \mathrm{GtCO}_{2} \mathrm{e}$ potential (uncertainty range 2.6-4.8 $\mathrm{GtCO}_{2} \mathrm{e}$ ) in 2030, after correction for overlap with the earlier measures. Hence, the total emission reduction potential is $6.7 \mathrm{GtCO}_{2} \mathrm{e}$ (uncertainty range $5.4-8 \mathrm{GtCO}_{2} \mathrm{e}$ ).

\subsection{Buildings}

We estimate that, for new buildings, between $0.68-0.85 \mathrm{GtCO}_{2}$ could be avoided in 2030 based on the method used by Reference [49]. This would require that all new buildings are near-zero energy in countries belonging to the Organisation for Economic Co-operation and Development (OECD) from 2020 onwards and, in non-OECD countries, from 2020 to 2025 onwards (variation in start year leading to the range in emission reductions). It is assumed that near-zero energy buildings have $90 \%$ lower emissions than the standard. This figure is consistent with Blok et al. [50], who estimated, based on an analysis of several studies, a potential of ambitious energy efficiency standards for new buildings of 0.7-1.3 $\mathrm{GtCO}_{2}$ in 2030. It is also comparable with Reference [51], which reports a reduction potential of $0.9 \mathrm{GtCO}_{2}$ in 2030 for heating efficiency in new buildings. The improvement measures can include the application of heat pumps; the numbers presented here represent the net avoided emissions.

For the thermal retrofit of existing buildings, the estimated emission reduction potential is $0.53-0.93$ $\mathrm{GtCO}_{2}$ in 2030, using the same method as in Reference [49]. The lower range requires annual renovation rates of $3 \%$ in OECD and non-OECD countries from 2020 onwards with $75 \%$ direct emissions reduction per retrofit [52]. The higher range requires annual renovation rates of $5 \%$ in OECD countries and of $3 \%$ in non-OECD, in both cases, from 2020 onwards, with $90 \%$ direct emissions reduction per retrofit [52]. These retrofit rates represent the highest reported in the literature. Typical historic retrofit rates are $1 \%$ per year; one of the highest numbers reported is for Germany, with a rate of just more than $2 \%$ [53]. The reduction potential is consistent with Reference [51], which estimates a reduction potential of $0.8 \mathrm{GtCO}_{2}$ in existing buildings for 2030. Note that also, in these cases, the net emission mitigation potential is reported, taking into account additional emissions in the power sector in the case of shifts from fuels to electricity, e.g., through the use of heat pumps. The combined savings for new buildings and building retrofits will lead to a reduction of the fuel use intensity of $33-60 \%$ in addition to what is achieved in the baseline (estimated to be $42-66 \%$ compared to 2015 frozen efficiency levels).

According to the International Renewable Energy Agency (IRENA) [54,55], heat from renewable sources can grow compared to the baseline by 5.4 EJ for solid, liquid, and gaseous biofuels and by 2.9 
EJ for solar energy. This equals an emission reduction potential of $0.39 \mathrm{GtCO}_{2}$ in 2030 from biomass and of $0.21 \mathrm{GtCO}_{2}$ for solar heat.

For electric appliances (excluding lighting) in households and the service sector, an assessment of the potential is calculated based on Reference [56], leading to an emission reduction potential of $3.3 \mathrm{GtCO}_{2}$ in 2030. This is in line with the estimation of adopting the world's best end-use equipment technology by the Collaborative Labeling and Appliance Standards Program (CLASP) [57]. For energy-efficient lighting, a report by UNEP [58] estimates energy savings of 4.4 EJ, equivalent to 0.92 $\mathrm{GtCO}_{2}$ in 2030. Molenbroek et al. [56] also reports emission reductions from lighting of $0.67 \mathrm{GtCO}_{2}$ in 2030. We will use this figure, which is slightly lower than the older estimate in Reference [57]. The total savings for appliances and lighting are equivalent to a reduction of the energy intensity in this category of $42 \%$ compared to the baseline (estimated to be $57 \%$ compared to 2015 frozen efficiency levels). Note that, in these numbers, only the impact of more efficient light sources is included and not other measures, such as more efficient luminaires. The same will apply to space cooling, for which better architectural design can save more than what can be achieved by efficient cooling equipment alone.

Efficient behaviour of end-users is an option that can also reduce greenhouse gas emissions; see, e.g., Reference [59]. Providing advanced feedback to households facilitated by new technology like smart meters and smart thermostats may save $5-15 \%$ in the EU or the US (see, e.g., References $[60,61]$ ). However, an estimate of the global emission mitigation potential is not available.

The total reduction potential for direct emissions from buildings is $1.9 \mathrm{GtCO}_{2} \mathrm{e}$ (uncertainty range 1.6-2.1 $\mathrm{GtCO}_{2} \mathrm{e}$ ) in 2030 after correction for overlap between energy efficiency and renewable energy measures. The reduction potential for indirect emissions is included in the potential for the energy production and conversion sector.

\subsection{Energy Production and Conversion}

A wide variety of emission reduction options exist in the power sector: a variety of renewable energy sources, nuclear energy, and carbon capture and storage (CCS). Emission reductions from the oil and gas sector and from coal mining are also discussed in this section.

There is a wide range of estimates of solar photovoltaic (PV) potentials [62,63]. Solar power capacity can reach $3725 \mathrm{GW}$ in 2030 [64] compared to $708 \mathrm{GW}$ in the reference scenario, which would provide an emission reduction of $3.0 \mathrm{GtCO}_{2}$ in 2030. The installed global solar capacity by the end of 2016 amounted to $303 \mathrm{GW}$ [65]; reaching these potentials would require an annual growth of installed capacity of $14-20 \%$ per year [64]. For comparison, the growth in the past decade amounted to $48 \%$ per year [65]. Some newer studies, however, provide higher potentials. A recent analysis by Breyer et al. [66] comes to a potential of 7100-9100 GW. This potential would require a growth of the installed solar PV capacity of $26-29 \%$ per year. For a more electrified energy system, Breyer et al. report a potential of 12,000 GW. Another study showed that, by scaling up the solar PV energy strategy of Germany to the whole world, solar PV, globally, could potentially increase in the range of $3885-8722$ GW by $2030[67,68]$. These potentials are also in range with those proposed by Haegel et al. [62]. Based on the large variety of numbers presented here and excluding the outliers, we come to a potential of 3-6 $\mathrm{GtCO}_{2}$ avoided through solar PV (total installed capacity 3700-8200 GW).

The installed global wind capacity by the end of 2016 was 487 GW [65]. Wind energy capacity can grow to between 2110 and $3064 \mathrm{GW}[64,69]$ compared to $940 \mathrm{GW}$ in the reference scenario in 2030. This provides an emission reduction between $2.6-4.1 \mathrm{GtCO}_{2}$; reaching these potentials would require an annual growth of installed capacity of $11-15 \%$ per year. For comparison, the growth in the past decade amounted to $21 \%$ per year [65].

There are also other electricity production options that have potential to reduce emissions in the power sector in 2030. Biomass has a potential of $0.85 \mathrm{GtCO}_{2}$ and geothermal has a potential of 0.73 $\mathrm{GtCO}_{2}$ compared to the baseline [64]. For hydro power and nuclear energy, the IEA [23] provides an indication for the potential of hydro and nuclear energy in its 450 scenario; with increases of 147 
GW and $154 \mathrm{GW}$ compared to the baseline, the reduction potential is estimated as 0.32 and $0.87 \mathrm{GtCO}_{2}$ in 2030, respectively.

The total emission reduction potential for carbon capture and storage is estimated by IEA [14] as $2.03 \mathrm{GtCO}_{2}$, which is slightly lower than the estimation by Mac Dowell and Fajardy [70] of $2.5 \mathrm{GtCO}_{2}$ based on an earlier IEA study. This includes a reduction of $0.8 \mathrm{GtCO}_{2}$ in 2030 for $\mathrm{CO}_{2}$ for enhanced oil recovery (EOR) and of $0.1 \mathrm{GtCO} 2$ in 2030 for carbon capture and utilisation (CCU). Based on the allocation in Reference [14], 67\% of the total potential will be allocated to the industry sector and 33\% will be allocated to the power sector. The amount of carbon dioxide avoided is smaller than the amount of carbon dioxide captured because operating CCS consumes energy as well. This ratio is $70-90 \%$ [71]. Therefore, we correct for the stored $\mathrm{CO}_{2}$ that is reported by applying a $20 \%$ discount. In the industrial sectors, a correction of $10 \%$ is applied since the $\mathrm{CO}_{2}$ in these sectors is often emitted at higher purity. Note that it is not certain that the entire CCS potential can be realised at costs below $100 \mathrm{USD} / \mathrm{tCO} 2$ (see Section 4.1).

Bioenergy with carbon capture and storage (BECCS) has a reduction potential of $0.31 \mathrm{GtCO}_{2}$ in 2030 [14]. Arasto et al. [72] estimate costs of 100-200 USD/tCO the average costs for BECCS to be $80-90 \mathrm{USD} / \mathrm{tCO}_{2}$ and Johnsen et al. [74] estimates that BECCS applied on biofuel production in 2030 will cost $€ 25-175 / \mathrm{tCO}_{2}$. Since there are studies with estimations under and above $100 \mathrm{USD} / \mathrm{tCO}_{2}$, the potential for BECCS will be allocated to the power sector category as an "additional" option.

We do not include the shift from coal to gas since natural gas declines in the World Energy Outlook 450 scenario compared to the baseline [22]. However, within certain regions, the shift from coal to gas can play a role in the reduction of emissions from the power sector; within the World Energy Outlook 450 scenario, there is only a small increase visible in India (0.3 EJ) and South Africa (0.04 EJ) [23]. Given the small size, this is not included in the potentials.

The total potential in the power sector is large-all numbers counted together make up about $60-80 \%$ of the current policy scenario emissions in the power sector when summing up all individual potentials, without considering overlap. Adding electricity savings from buildings and the industry sector have the potential to avoid the full current policy emissions in the power sector, bringing the total to over $10 \%$, which is obviously not possible unless BECCS is applied on a large scale. However, already long before the $100 \%$ is reached, there will be increasing interactions between the different options, making the total potential smaller than the sum of the options. In the overall assessment, we assume that total emissions in the power sector are not reduced by more than $57-65 \%$, which are the largest fractions found in the literature $[64,75]$; this will lead to total emission reductions of $9.3-10.6 \mathrm{GtCO}_{2}$.

Outside the power sector, methane emissions from the distribution of gas and the production and transmission of oil and gas can be reduced by $1.78 \mathrm{GtCO}_{2}$ in 2030 [35]. This is $75 \%$ of the baseline emissions from the oil and gas industry. These reductions can mainly be achieved by implementation of measures for the recovery and utilization of vented gas and the reduction of leakages.

Methane emissions from coal mining can be reduced by $0.41 \mathrm{GtCO}_{2} \mathrm{e}$ in 2030 , which is a reduction of $56 \%$ compared to the current policy scenario [35]. Measures implemented in this scenario include pre-mining degasification measures and the installation of ventilation air oxidisers.

Combining the potentials of all the electricity-related measures discussed in buildings and the industry leads to a potential of $10.0 \mathrm{GtCO}_{2} \mathrm{e}$ (range 9.3-10.6 $\mathrm{GtCO}_{2} \mathrm{e}$ ) in 2030. BECCS could provide an additional potential of $0.3 \mathrm{GtCO}_{2} \mathrm{e}$ in 2030 (range 0.2-0.4 $\mathrm{GtCO}_{2} \mathrm{e}$ ). Emission reductions from the oil and gas sector and from coal mining are $2.2 \mathrm{GtCO}_{2} \mathrm{e}$ (range 1.7-2.6 $\mathrm{GtCO}_{2} \mathrm{e}$ ).

\subsection{Forestry}

There are two main options in the forestry category: halting deforestation and restoration of degraded forest land. Emission reduction potentials from halting deforestation come with great uncertainty. These uncertainties relate, for example, to the degree to which decreased deforestation 
leads to lowered degradation and associated carbon emissions and to which baseline is used [43]. We assume a global potential in 2030 of $3 \mathrm{GtCO}_{2} \mathrm{e}$ (based on Reference [4]).

Global commitments on the restoration of degraded forests aim to bring a total of 350 million ha of degraded and deforested land under restoration, such as commitments to the Bonn Challenge and the New York Declaration on Forests [76]. Reaching this target by 2030 would yield emission reductions in the order of 1.6-3.4 $\mathrm{GtCO}_{2}$, with a central estimate of $2.3 \mathrm{GtCO}_{2}$ in 2030 [77].

Combining the potentials of the measures discussed leads to a total contribution from the forestry sector of $5.3 \mathrm{GtCO}_{2} \mathrm{e}$ (with an uncertainty range of 4.1-6.5 $\mathrm{GtCO}_{2} \mathrm{e}$ ).

\subsection{Manufacturing Industry}

Two main options of industrial GHG emission reduction are energy efficiency improvement of fuel and electricity use. There are also smaller sources of GHG emissions including "non-energy" use of fossil fuels (e.g., fossil fuels as feedstock for chemical processes) and emissions from industrial processes (for example, calcination in the cement process and several sources of non- $\mathrm{CO}_{2} \mathrm{GHGs}$ ).

For energy efficiency, the emission reduction potential for 2030 is estimated at $4.1 \mathrm{GtCO}_{2}$ compared to the current policy scenario. This estimate is based on data from ClimateWorks Foundation and the World Bank [78], scaled up from six major regions to the entire world and correcting for measures other than energy efficiency. The analysis [78] covers all sectors. Both sector-specific technologies and cross-cutting technologies (like heat recovery and energy-efficient motor systems) are included. The emission reduction means an additional reduction of the energy intensity of nearly 30\% compared to the current policy scenario (estimated to be $40 \%$ compared to 2015 frozen efficiency levels). This is compatible with the estimate by Worrell and Carreon [79] (see also Reference [80]), who estimated a static potential of $27 \pm 9 \%$. Note that the potentials vary by sector and by region. For example, Worrell and Carreon estimate them to be 9 to 30\% for iron and steel, 4 to $7 \%$ for primary aluminium, 20 to $25 \%$ for cement, 23 to $27 \%$ for petrochemicals, and 11 to $25 \%$ for ammonia production [79]. Based on the share in current policy emissions, $2.2 \mathrm{GtCO}_{2}$ emission reduction is allocated to direct emissions and 1.9 $\mathrm{GtCO}_{2}$ is allocated to indirect emissions.

Renewable energy use in the form of solid, liquid, and gaseous biofuels; solar thermal energy; and geothermal can generate $9.7 \mathrm{EJ}$ [54], which is an additional $7.8 \mathrm{EJ}$ compared to the current policy scenario. This will save $0.5 \mathrm{GtCO}_{2}$ in 2030 .

Carbon capture and storage in the manufacturing industry has an emission reduction potential of $1.22 \mathrm{GtCO}_{2}$ in 2030; see the discussion of this option in the subsection on energy production and conversion.

For non- $\mathrm{CO}_{2}$ greenhouse gases, the largest reduction is from HFCs, which can be reduced by 1.5 $\mathrm{GtCO}_{2} \mathrm{e}$ in 2030 [36]. USEPA [38] estimates a reduction potential for other non- $\mathrm{CO}_{2} \mathrm{GHG}$ emissions of $0.2 \mathrm{GtCO}_{2} \mathrm{e}$ in 2030, where $0.12 \mathrm{GtCO}_{2} \mathrm{e}$ comes from nitric and adipic acid production and the rest is from reducing PFCs from primary aluminium production and $\mathrm{SF}_{6}$ from electric power systems and magnesium production.

Measures to reduce the use of materials in society, like steel, cement, and plastics, can significantly reduce emissions. This option is often called "dematerialization", but no quantitative assessments are available for 2030. A study by Ecofys and Circle Economy [81] reports that circular economy measures can reduce emissions in 2030 by $9.7 \mathrm{GtCO}_{2}$. This number overlaps significantly with other measures and is therefore not included in the overall add-up.

Based on the above, the reduction potential for the industry for the reduction of direct emissions is $5.4 \mathrm{GtCO}_{2} \mathrm{e}$ in 2030 (range 4.2-6.6 $\mathrm{GtCO}_{2} \mathrm{e}$ ). No correction for overlap is needed, as many industrial plants are so large that energy efficiency measures can be combined with CCS or bioenergy, given the relatively small potentials of the latter. The reduction potential of indirect emissions is already accounted for in the potential for the energy supply sector. 


\subsection{Transport}

The emission reduction potential differs per mode of transport but is most significant for light-duty vehicles and heavy-duty vehicles, with other contributions coming from shipping, aviation, and biofuels.

In the automobile sector, fuel efficiency measures could potentially reduce emissions by 0.88 $\mathrm{GtCO}_{2}$ (high duty vehicles) and by $2.0 \mathrm{GtCO}_{2}$ (light duty vehicles) by 2030 [82]. These numbers include modal shifts, e.g., to public transport or nonmotorized transport. A shift to more electric vehicles is also included. The International Council on Clean Transportation (ICCT) [82] assumes that electric-drive vehicles will form a small but not insignificant share (up to 9\%) of new-vehicle sales by 2030. This is in line with the estimations of IRENA [54] (10\%). More recent sources, for example, Bloomberg New Energy Finance [83], consider higher market shares feasible (28\% in 2030); no analysis is available on the impact on global emissions in 2030, though. More use of nonmotorized transport, like cycling, can lead to significant emission reductions [84], but we have not included this as a separate option, as modal shifts are already included in the estimates of the ICCT. Note that substantial emission reductions due to fuel economy standards for passenger cars are already included in the current policy scenario.

Aviation can reduce emissions by $0.32-0.42 \mathrm{GtCO}_{2}$ in 2030 by using alternative fuels, improved infrastructure use, and technical improvements $[82,85]$.

Several studies indicated an emission reduction for shipping [86-89], ranging from 0.39 to 0.99 $\mathrm{GtCO}_{2}$. The studies contain several measures focused on fuel efficiency. The most recent study, from Bouman et al. [90], reports an emission reduction potential of $0.70 \mathrm{GtCO}_{2}$ in 2030. The numbers for aviation and shipping are in the same order as those in the study from New Climate Economy [91], which shows a reduction potential between 0.60 and $0.90 \mathrm{GtCO}_{2}$ per year.

Another measure that is relevant for the transport sector is the application of biofuels. ICCT [82] provides no potential for biofuels due to the high uncertainty. IRENA [54] does provide an estimate for biofuels to cover $10 \%$ of the sector's total fuel use in 2030. Taking into account that greenhouse gas emissions from biofuels are 70-90\% lower than those of conventional fuels [92], an emission reduction potential of 0.63 to $0.81 \mathrm{GtCO}_{2} \mathrm{e}$ in 2030 can be calculated.

Based on the above, the total emission reduction potential for the transport sector is $4.7 \mathrm{GtCO}_{2} \mathrm{e}$ in 2030 (with an uncertainty of 4.1-5.3 $\mathrm{GtCO}_{2} \mathrm{e}$ ). No overlap correction is needed, as biofuels can be used as drop-in fuels. The energy efficiency measures alone will lead to a total sector energy intensity reduction of $42 \%$ compared to the baseline (estimated to be $54 \%$ compared to 2015 frozen efficiency levels).

\subsection{Other}

Some options for emission reduction are difficult to allocate to one of the sectors assessed in the previous sections. This may be because it is still unknown in which sector it can best be implemented or because the option can be applied to multiple sectors. Some promising mitigation measures are described below.

Methane constitutes some $90 \%$ of GHG emissions from the waste sector. An emission reduction option is landfill gas recovery and utilization. USEPA [38] estimates that landfill gas recovery can reduce emissions by $0.4 \mathrm{GtCO}_{2} \mathrm{e}$ in 2030 , which is $42 \%$ of the emissions in the current policy scenario.

Enhanced weathering measures aim to draw carbon from the atmosphere via, among others, the natural chemical weathering process of silicates. Biogeochemical activity in soils naturally accelerates the weathering of rock and thereby leaches out calcium and magnesium, which then reacts with dissolved $\mathrm{CO}_{2}\left(\mathrm{HCO}_{3}{ }^{-}\right.$and $\left.\mathrm{CO}_{3}{ }^{2-}\right)$ [93]. First global estimates, assuming use of wastes from the cement, iron, and steel and from the power industry, arrive at $0.73-1.22 \mathrm{GtCO}_{2} \mathrm{e}$ [94].

Direct capture of atmospheric $\mathrm{CO}_{2}$ from air is not included as the costs seem to be larger than USD100/tCO $\mathrm{t}_{2} \mathrm{e}$ [95]. 


\section{Total Emission Reduction Potentials}

\subsection{Total Emission Reduction Potential}

An overview of the estimated total emission reduction potentials in 2030 assessed in the previous section is provided in Table 2. The table shows that emission reduction categories have a longer history of assessment, which we indicate as the "basic potential", leading to a total emission reduction potential in 2030 of $33 \mathrm{GtCO}_{2} \mathrm{e}$ (uncertainty range 30-36 $\mathrm{GtCO}_{2} \mathrm{e}$ ). If we consider, in addition, that options for which estimates of emission reduction potentials are relatively new and the feasibility of realising these in 2030 is more uncertain (the "additional potential"), we get to a total potential of $38 \mathrm{GtCO}_{2} \mathrm{e}$ (range $\left.35-41 \mathrm{GtCO}_{2} \mathrm{e}\right)$. A sectoral breakdown is presented in Figure 1.

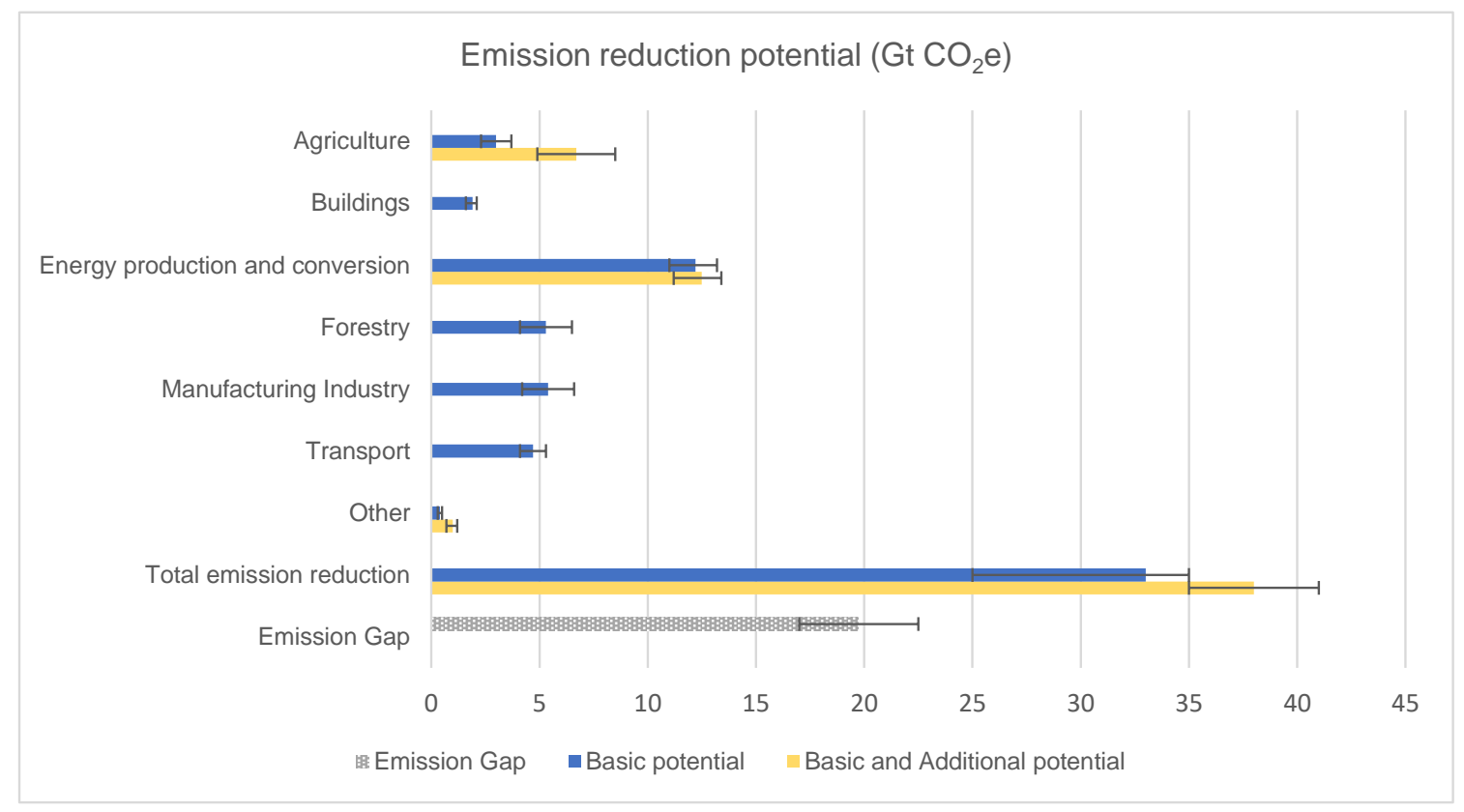

Figure 1. Sectoral emission reduction potentials at the global level compared to the total emissions gap in 2030: Note that electricity efficiency options are included in the sector energy production and conversion and not in the end-use sectors buildings and manufacturing industry. The total potential is compared with the emission gap (see text for definition) [96].

According to the 2017 emissions gap report [96], the difference in 2030 between emissions under the current policy scenario and the emission levels consistent with a likely chance of staying below $2{ }^{\circ} \mathrm{C}$ ( $>66 \%$ probability) and a medium chance of staying below $1.5{ }^{\circ} \mathrm{C}$ (50-66\% probability) are respectively 17 and $22.5 \mathrm{GtCO}_{2} \mathrm{e}$. Importantly, even if only the basic emission reduction potential for 2030 is considered, the estimated total potential listed in this report is more than sufficient to bridge the emissions gap in 2030 for $2^{\circ} \mathrm{C}$ and $1.5^{\circ} \mathrm{C}$. 
Table 2. Overview of emission reduction potentials: Although for many emission reduction categories a single point estimate is given, there are always uncertainties, assumed to be $\pm 25 \%$. For the categories of peatland degradation and peat fires, biochar, and the various energy efficiency measures, the potential in 2030 is more uncertain. Therefore, a higher uncertainty range of $50 \%$ is applied for these categories. In the final column, the categories are aggregated to the sectoral level (see discussion in the text). The numbers in the third column are not corrected for overlap between measures. The numbers in the final column are corrected for overlap, and this is also reflected in the total potential. Therefore, the total is smaller than the sum of the individual potentials in the third column. The aggregate potentials for indirect emission reductions in buildings and industry are reflected in the electricity sector potential.

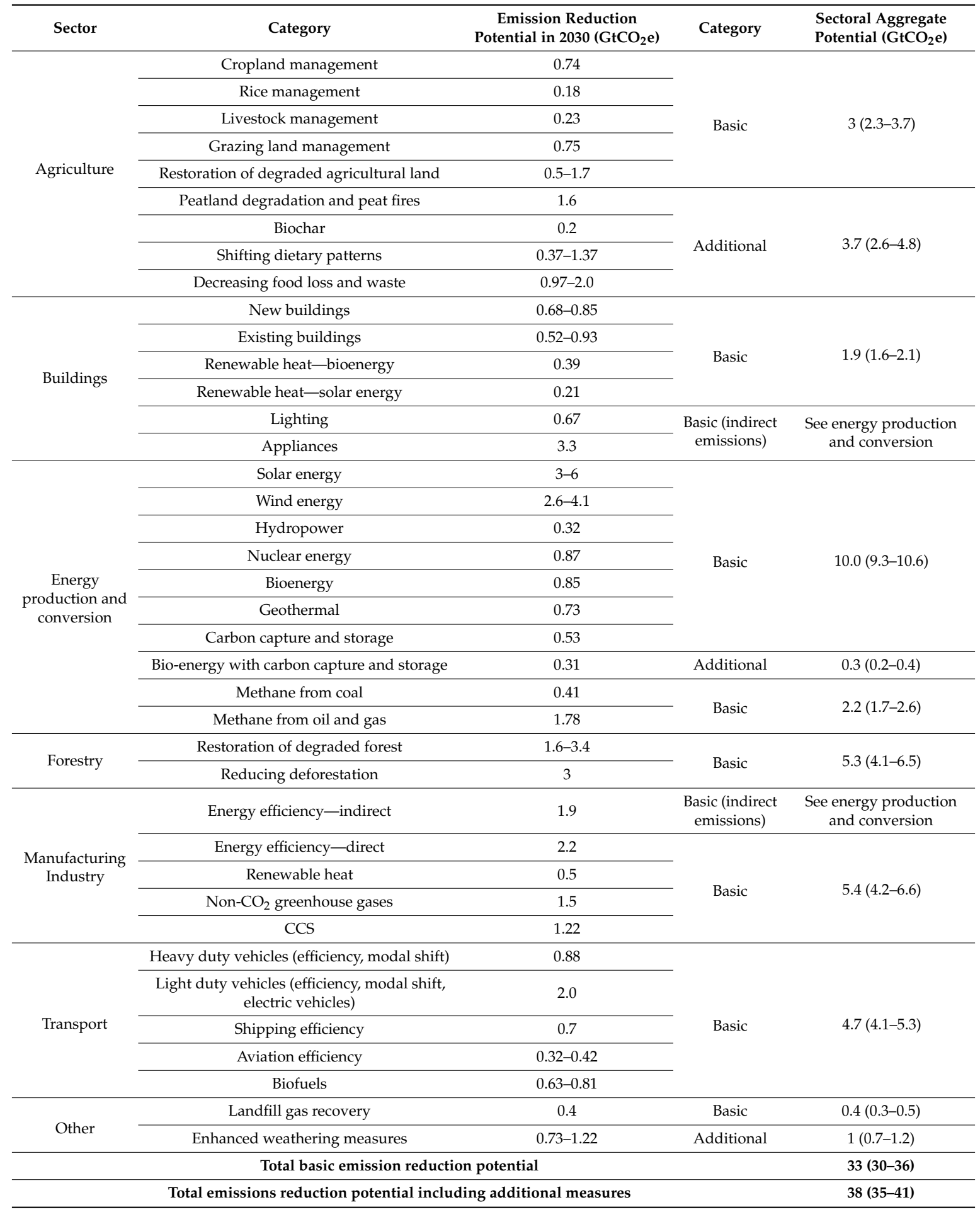




\subsection{Discussion on Sectoral Emission Reduction Potentials}

The sectoral assessment of emission reduction options relies on a variety of secondary sources, including both peer-reviewed and grey literature. Especially for the grey literature, we have carefully examined the sources that we used for quality and completeness. Use of grey literature is not necessarily a drawback: it can bring in expertise from outside academia and, sometimes, is more up to date. Nevertheless, there are still options for which limited information is available, e.g., the global mitigation impact of circular economy options and changes in end-user behavior, so these are missing from the overall analysis. Also, the potential impact of the introduction of new intermediate energy carriers, like hydrogen produced with electricity from renewable sources, is still insufficiently investigated.

Although the available studies prevent an explicit, economic assessment of all emission reduction options, there is a relatively high degree of confidence that all options included in Table 2 have costs below USD100 per $\mathrm{tCO}_{2} \mathrm{e}$ avoided. In many cases, this is explicitly mentioned in the source documents (referred to Section 3); in the remaining cases, this is supported by other sources [97,98]. For some, however, it is not clear whether the costs will fall below USD100/ $\mathrm{tCO}_{2} \mathrm{e}$. For example, some electricity sources may show costs above USD100/tCO $\mathrm{CO}_{2} \mathrm{e}$ in specific cases, as there are large variations in costs [98]. However, given that there are abundant options in the electricity sector, leaving out these options will not affect the total potential.

Energy efficiency options are spread across the sectors (including the sector energy production and conversion; electricity efficiency options are included there). They make up a substantial part of the emission mitigation potential: about $13 \mathrm{GtCO}_{2} \mathrm{e}$. Nevertheless, this is also the area for which calculations of the global potential are relatively rare and better analysis is needed to get to more precise potential estimates. There are indications that the potential might be higher than what is presented in this assessment; see, for example, Reference [99]. One area that deserves specific mention is that of electric vehicles, where potentials currently are estimated to be higher than what we derived from our primary source. Another area that was not at all included in our analysis is material efficiency and other circular-economy-related options because of the lack of global analysis (see Section 3.5). The high potential of reducing emissions by demand-side measures is also confirmed by Grübler et al. [100], leading to a level of final energy use in 2050 of 245 EJ (for comparison, in 2014, global final energy use was approx. $400 \mathrm{EJ}$ [23]). Our results also indicate that there is a potential for final energy use to already decline in 2030, compared to current levels.

The $30-36 \mathrm{GtCO}_{2} \mathrm{e}$ range found in this article is at the high end of the range of $15.8-31.1 \mathrm{GtCO}_{2} \mathrm{e}$ found in the Fourth Assessment Report of the IPCC [10], even if we exclude the additional potential. Note that the IPCC report starts from a 7\% lower baseline. A detailed comparison can be found in Table 3. In the current study, we find higher potentials for energy production and conversion (especially for solar and wind energy), the forestry sector (higher potentials for reforestation), the industry sector (higher potentials for electricity efficiency), and the transport sector (higher potential for fuel efficiency in all transportation modes). In most of these cases, the higher potential estimates that we find now may probably be related to a favourable development of the technology (e.g., much lower costs for solar PV) or further exploration of the options. The potential estimate of $38 \mathrm{GtCO}_{2} \mathrm{e}$ that was reported by McKinsey [11] is in the high end of our range, but their baseline emissions are also not current policies but rather business-as-usual and 15\% higher; note that McKinsey included some options that we did not include, e.g., recycling. Our total results for agriculture and forestry of about $11 \mathrm{GtCO}_{2} \mathrm{e}$ for the agriculture and forestry sectors compare well with the $11.3 \mathrm{GtCO}_{2} \mathrm{e}$ found in the recent study by Griscom et al. [101] for "natural climate solutions" (although they did not include demand-side measures like dietary changes and prevention of food waste). For a comparison with the results of integrated assessment models, see Section 4.3.

Note that we counted all potentials together on the basis of global warming potentials (GWPs) with a time horizon of 100 years. This approach is the only suitable one if potentials for one specific year are given. Nevertheless, it has its limitations, given that the reduction of relatively short-lived 
substances (like methane) will have a higher short-term impact than a similar $\mathrm{CO}_{2}$-equivalent emission reduction impact of long-lived substances (like $\mathrm{N}_{2} \mathrm{O}$ ).

Table 3. Comparison of our results to those of the Fourth Assessment Report of the Intergovernmental Panel on Climate Change (IPCC) (in $\mathrm{GtCO}_{2} \mathrm{e}$ ): Note that, in this table, the emission reductions due to electricity savings in buildings and industry in this table are counted with the energy production and conversion sector, whereas in the Summary for Policy Makers of the IPCC report, they are counted with the buildings and industry sector. Here, the respective emission reductions from the IPCC report are reallocated to the energy production and conversion sector.

\begin{tabular}{lcc}
\hline & IPCC (2007) & $\begin{array}{c}\text { This Study Basic Potential } \\
\text { (in Parenthesis Additional Potential) }\end{array}$ \\
\hline Agriculture & $2.3-6.4$ & $2.3-3.7(2.6-4.8)$ \\
Buildings & $2.3-2.9$ & $1.6-2.1$ \\
Energy production and conversion & $6.2-9.3$ & $11.4-13.0(0.2-0.4)$ \\
Forestry & $1.3-4.2$ & $4.1-6.5$ \\
Manufacturing Industry & $2.3-4.9$ & $4.2-6.6$ \\
Transport & $1.6-2.5$ & $4.1-5.3$ \\
Waste & $0.4-1.0$ & $0.3-0.5$ \\
\hline
\end{tabular}

An important question is what the efforts and costs are of realising these emission reductions. Although it is beyond the scope of the current article to answer this question in full, a number of observations can be made. It is remarkable that a large part of the potential consists of just six relatively homogeneous categories, that is, solar and wind energy, efficient appliances, efficient passenger cars, afforestation, and stopping deforestation; they sum up to a potential of $18.5 \mathrm{GtCO}_{2} \mathrm{e}$ in 2030 (range: $15-22 \mathrm{GtCO}_{2} \mathrm{e}$ ), making up more than half of the basic potential. Equally important, all these measures can be realised at modest or in some cases even net-negative costs and are predominantly achievable through proven policies. Solar PV and wind energy: Many countries around the world have targets for renewable energy and have policies in place to stimulate the adoption. The most dominant policy instruments are feed-in tariffs or feed-in premiums, which have been implemented in 75 countries and 29 states or provinces in the world, providing long-term power purchase agreements with a specified price or premium price per $\mathrm{kWh}$ for a renewable energy technology [65]. An instrument with increasing popularity is competitive bidding or auctioning, especially for large-scale developments, where the renewable energy market is mature and governments have already achieved a degree of success with renewable energy installation through feed-in tariffs [65]. Costs of electricity from solar and wind electricity have already declined to levels comparable with fossil-fuel-based electricity [98], and auctions have accelerated this trend [102]. Continuation of feed-in policies and/or a shift to auctions are a straightforward and cheap approach to rapid decarbonisation of the power sector. Energy-efficient appliances and cars: To stimulate the uptake of efficient appliances, the combination of labelling and minimum energy performance standards are the dominant policies. Over 60 countries have adopted or pledged to adopt policies to shift to more energy-efficient lighting [58]. Under the united for efficiency (U4E) public-private-partnership, UN Environment is supporting developing countries and emerging economies to move their markets to energy-efficient appliances and equipment [96]. In terms of performance standards for cars, countries have opted to implement fuel economy standards in miles per gallon or $\mathrm{CO}_{2}$ emission standards in $\mathrm{gCO}_{2}$ per $\mathrm{km}$; these standards exist in Brazil, the EU, India, Japan, Mexico, and the USA [103]. Typically, energy efficiency standards are implemented in such a way that lifecycle costs are minimized, hence leading to net-negative costs for the consumer. Similar policies are in place for new building construction [104]. Further continuation of these policies, scaling them up to more countries while raising ambitions, is a way forward to limit the growth of energy use and hence to reduce emissions. Stopping deforestation and restoration of degraded forests: There are several examples of policies successfully stopping deforestation, the most large-scale being the Brazilian "Action Plan for Prevention and Control of Deforestation in the Amazon", consisting of (1) territorial and 
land-use planning, (2) environmental control and monitoring, and (3) fostering sustainable production activities. The programme led to a reduction of the deforestation rate by over $80 \%$. Costs are found to be on average USD13/tCO $\mathrm{CO}_{2} \mathrm{e}[67,68]$. For reforestation of degraded forests, the scale of operations is not that size, but promising examples are available for China [105], Costa Rica [67,68], and the Republic of Korea [106]. Costs are comparable with the costs of stopping deforestation.

\subsection{Comparison of the Sectoral Results with Results from Integrated Assessment Models}

The results of the bottom-up sector-by-sector assessment can be compared with the sectoral emissions as reported by a range of state-of-the-art integrated assessment models (IAMs). This is useful because IAMs provide information on how a given climate target can be achieved in a "least-cost" way through a full cost comparison across all sectors and by taking into account the interactions between the different reduction options and the interactions with the wider economy. Since the scenarios we discuss here stay within the $2{ }^{\circ} \mathrm{C}$ and $1.5^{\circ} \mathrm{C}$ targets, they also bridge the gap between current policy emissions in 2030 and the emissions in line with the $2{ }^{\circ} \mathrm{C}$ and $1.5^{\circ} \mathrm{C}$ targets. Hence, the package of mitigation measures identified in the scenarios can be viewed as successful examples of how to close the gap. For the comparison, we use the baseline of the Shared Socioeconomic Pathways (SSP), a new scenario framework facilitating the integrated analysis of future climate policy and impacts [107]. The SSP2 scenario is the "middle-of-the-road" scenario of the Shared Socioeconomic Pathways. Six IAMs have been used to quantify the SSP scenarios, namely AIM/CGE, GCAM, IMAGE, MESSAGE-GLOBIOM, REMIND, and WITCH. AIM/CGE, REMIND, and WITCH are general equilibrium models using intertemporal optimization solution algorithms. The other three models use a recursive dynamic approach, with for GCAM a partial equilibrium framework, and for IMAGE and MESSAGE-GLOBIOM, a hybrid form [107]. Subsequently, we compare the derived mitigation scenarios aiming for a likely (>66\%) probability of staying below $2{ }^{\circ} \mathrm{C}$, with bottom-up assessment of the mitigation potential. It should be noted that the SSP2 baseline scenarios range from $62-69 \mathrm{GtCO}_{2} \mathrm{e}$, which is higher than the baseline emissions used in the sectoral assessment, i.e., $61.1 \mathrm{GtCO}_{2} \mathrm{e}$ (Table 1). The reason is that SSP2 shows emission development in the absence of climate policies, whereas the baseline of the sector-by-sector analysis is a current-policies scenario. Estimates of current policy scenarios in IAM models (e.g., Reference [108]) show a similar emission range as included in Table 1.

At the sector level, the projections from integrated assessment models show that baseline emissions can grow rapidly in industry and transport sectors. Direct emissions from the buildings sector, in contrast, are projected to grow only slowly or to even stabilize due to an increase in electrification rates [109]. Figure 2 also shows that a similar sectoral pattern emerges in the SSP2 set as in the sector-by-sector analysis, which implies that it is possible to also compare the mitigation potential. While in the electricity and agriculture sector the sector-by-sector baseline emissions are significantly below the average of the IAMs, they are in most sectors within or close to the total range reported by the IAMs.

Figure 3 compares the emission reduction potentials of the sector-by-sector technology-based analysis with the mitigation activities in the IAM set for the $2{ }^{\circ} \mathrm{C}$ scenario, noting that the IAMs assume a slightly higher total 2030 emission level. The average total mitigation in 2030 in the IAM scenarios is $23 \mathrm{GtCO}_{2} \mathrm{e}$, with a full range of $5-42 \mathrm{GtCO}_{2} \mathrm{e}$. The wide range across the IAMs is caused by different reduction strategies over time and different baseline assumptions. Overall, the IAM range reductions from the baseline are lower than the total emission reduction potential found in the sector-by-sector analysis, providing evidence that the IAM scenarios are technically feasible. The sectoral breakdown shows that, in the electricity sector, emission reductions are comparable, although the IAMs show a very wide range for this sector. This is also true for the underlying contribution of increased use of renewable and nuclear power, fossil-fuel and CCS, fuel switch, and bioenergy and CCS. Typically, however, IAMs show a relatively high contribution of bioenergy and fossil fuel CCS technology, certainly also for the long term. This highlights the importance of research and development with respect to negative emission options even though their role might still be limited on the short term. For the various end-use 
sectors, the IAMs show considerably less emission reduction than the sector-by-sector estimates. In the literature, this is explained by 1) the relatively large implementation barriers complicating emission reductions in these sectors and 2) the possible predominant focus of IAM models on energy supply [5]. While the sectoral, bottom-up assessment finds energy efficiency improvements more important than fuel switching to renewable energy sources in the end-use sections, IAM results show both measures to be equally important. The emission reduction potential of biological carbon removal by means of reforestation and increasing carbon in agricultural soil is also less in IAMs than in the sector-by-sector assessment. It should be noted, however, that IAMs in general do not consider the option of increasing carbon in agricultural soils. Finally, for non- $\mathrm{CO}_{2}$ greenhouse gases, a similar picture emerges: the emission reduction in the IAM $2{ }^{\circ} \mathrm{C}$ scenarios is smaller than the total potential of the sector-by-sector analysis.

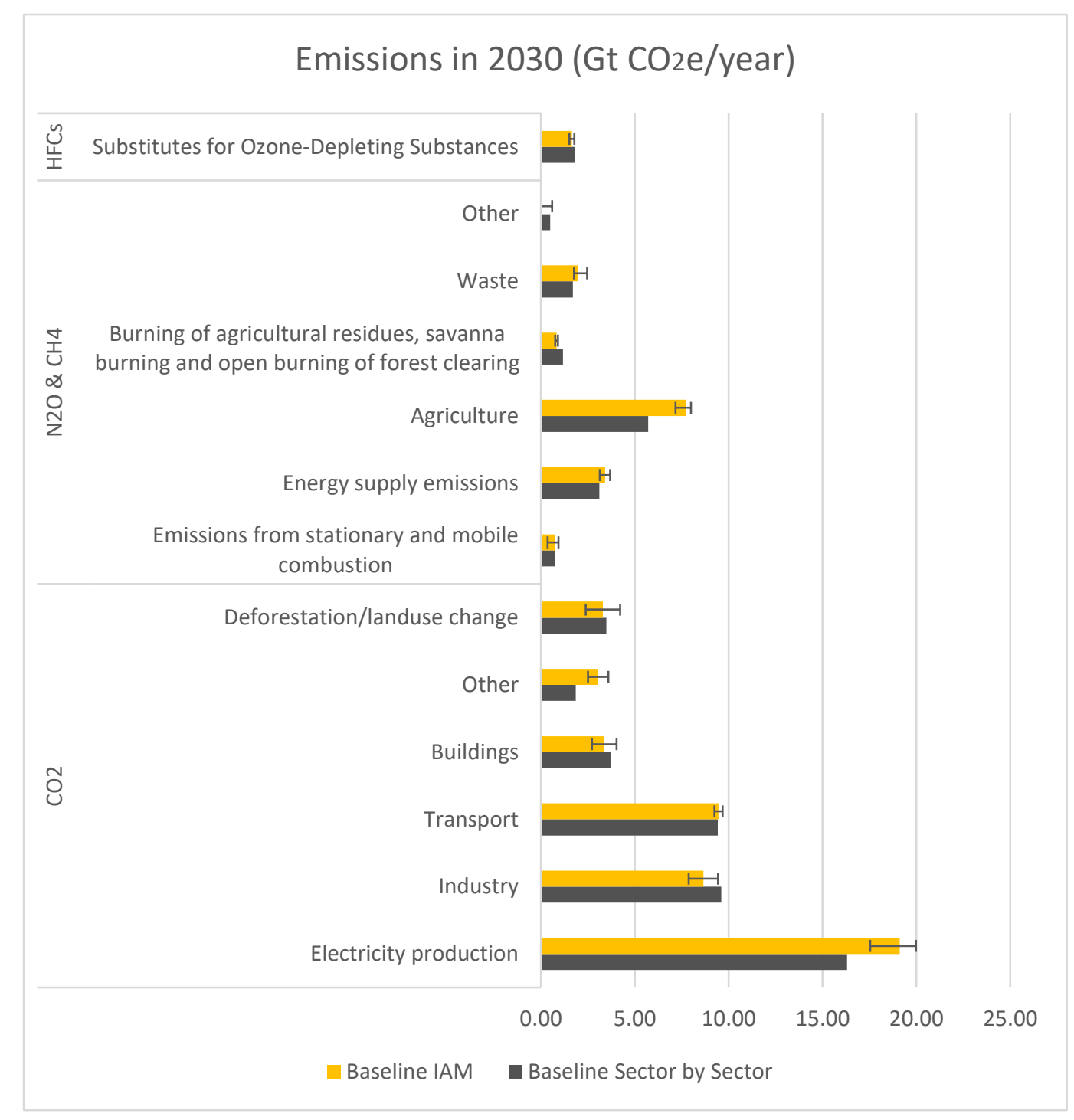

Figure 2. Comparison of the 2030 baseline emissions in the sector-by-sector analysis with the baselines assumed in the 6 integrated assessment models: The integrated assessment model (IAM) results show the mean and the $15-85 \%$ percentile range. For the latter, the average, highest, and lowest values are given. 


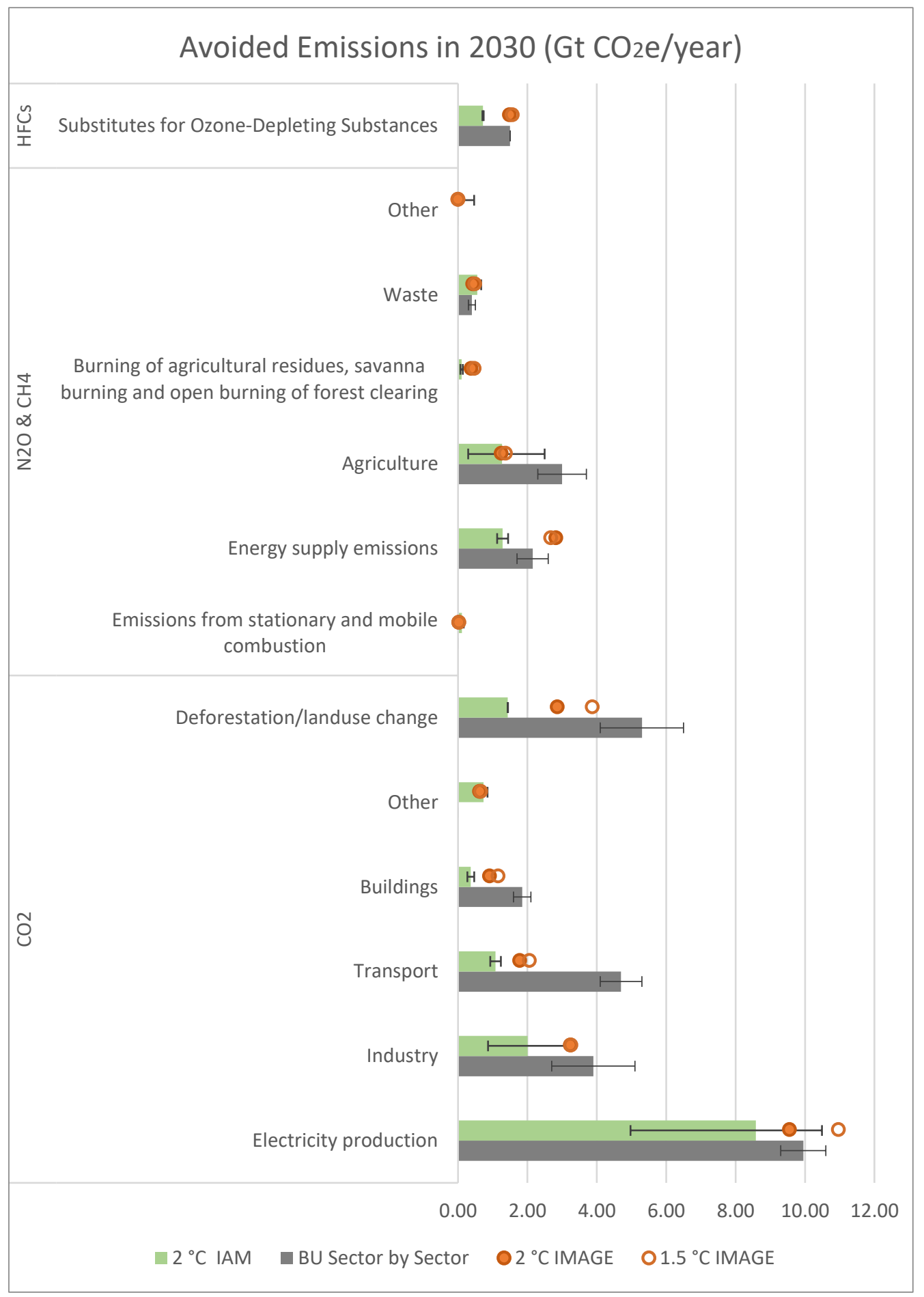

Figure 3. Comparison of mitigation in the IAMs under a $2{ }^{\circ} \mathrm{C}$ pathway with the emission reduction potentials found in the sector-by-sector analysis: The IAM results show the mean and the 15-85 percentile range. The red dots indicate the reduction in the IMAGE model for both $2{ }^{\circ} \mathrm{C}$ and $1.5^{\circ} \mathrm{C}$ (in some cases, the IMAGE numbers are outside the $15-85 \%$ percentile of the IAM uncertainty range).

It is not possible to compare the sector-by-sector analysis with the IAM models for $1.5^{\circ} \mathrm{C}$ because most of these IAM scenarios were not published at the time of analysis. However, focusing on the results of one IAM, the IMAGE model, Figure 3 shows the IMAGE results for both $2{ }^{\circ} \mathrm{C}$ and $1.5^{\circ} \mathrm{C}$. The figure shows that moving to the more ambitious target requires scaling up emission reductions in several sectors, including the electricity sector and most end-use sectors. 
In conclusion, the emission reductions of the IAM $2{ }^{\circ} \mathrm{C}$ scenarios as well as the IMAGE $1.5^{\circ} \mathrm{C}$ are typically within the overall sector-specific potential of the bottom-up assessment. The electricity sector is an exception, but here, it should be noted that the current policy emissions in the bottom-up assessment were lower than for the IAMs. The analysis also suggests that further reductions in the IAM scenarios could mostly be achieved via energy efficiency and biological carbon removal options.

\section{Conclusions}

The analysis confirms the potential to close the global emissions gap with measures that are technically and economically feasible to implement by 2030 at a marginal cost of no more than USD100/ $\mathrm{tCO}_{2} \mathrm{e}$. The total potential is more than sufficient to bridge the total emissions gap in 2030 between the current policy trajectory and the emissions consistent with a $2{ }^{\circ} \mathrm{C}$ and a $1.5^{\circ} \mathrm{C}$ temperature target.

All sectors present substantial emission reduction potentials, which add up to a total of $33 \mathrm{GtCO}_{2} \mathrm{e}$ in 2030 (range: 30-36). This sum does not include potentials of fairly new measures (such as direct capture of atmospheric $\mathrm{CO}_{2}$, decreasing food loss and waste, and biochar) because it is uncertain whether these could realise their estimated emission reduction potentials by 2030 . We also found that just six options, i.e., wind energy, solar energy, efficient cars, efficient appliances, reforestation, and stopping deforestation already provide a potential of $15-22 \mathrm{GtCO}_{2} \mathrm{e}$, making up more than half of the potential just mentioned. These are also options for which policies are available that have proven successful in many countries.

In 2015, in the preparation phase for the Paris Agreement, countries have committed themselves in their Nationally Determined Contributions (NDCs) to realise quantified emission reductions. The NDCs of all countries together aim for an emission reduction of 4-6 $\mathrm{GtCO}_{2} \mathrm{e}$ compared to a current policy scenario (10-12 $\mathrm{GtCO}_{2} \mathrm{e}$ compared to a no policy scenario). This year, in 2020, countries are requested to enhance the ambition of their NDCs. This analysis shows that there is ample potential to increase the contributions. To realise the full emission reduction potential reported here, countries need to implement ambitious policies to enable and accelerate the implementation of the full socioeconomic potential of available measures and technologies.

Author Contributions: Conceptualization, K.B.; data curation, T.B., I.v.d.H. and O.Y.E.; investigation, K.B., A.A., T.B., I.v.d.H and O.Y.E; methodology, K.B. and D.P.v.V.; supervision, A.A. and D.P.v.V.; writing一original draft, K.B. and T.B.; writing-review \& editing, A.A.; funding acquisition: A.A. and K.B. All authors have read and agreed to the published version of the manuscript.

Funding: This research was funded by the Finnish Innovation Fund Sitra; by the Ministry of Infrastructure, Public Works, and Water Management of the Netherlands; and by UN Environment.

Acknowledgments: The authors wish to thank the funders for financially supporting this research. They want to thank Hans Joosten, Pete Smith, Saran Sohi, and Paul Waide for providing critical information for this work. We also wish to thank these persons and Ann Gardiner, Danny Harvey, Lynn Price, Roberto Schaefer, and Oras Tynkkynnen for providing comments to an earlier version of this article.

Conflicts of Interest: The authors declare no conflict of interest.

\section{References}

1. Rogelj, J.; Shindell, D.; Jiang, K.; Fifita, S.; Forster, P.; Ginzburg, V.; Handa, C.; Kheshgi, H.; Kobayashi, S.; Kriegler, E.; et al. 2018: Mitigation Pathways Compatible with $1.5^{\circ} \mathrm{C}$ in the Context of Sustainable Development. In Global Warming of $1.5^{\circ} \mathrm{C}$; IPCC: Geneva, Switzerland, 2018; in press.

2. UNEP. Emission Gap Report 2018; United Nations Environment Programme (UNEP): Nairobi, Kenya, 2018.

3. Bertoldi, P. The Paris Agreement $1.5^{\circ} \mathrm{C}$ goal: What does it mean for energy efficiency. In Proceedings of the ACEEE Summer Study on Energy Efficiency in Buildings; ACEEE: Washington, DC, USA, 2018.

4. Clarke, L.; Jiang, K.; Akimoto, K.; Babiker, M.; Blanford, G.; Fisher-Vanden, K.; Hourcade, J.-C.; Krey, V.; Kriegler, E.; Löschel, A.; et al. Assessing Transformation Pathways. In Climate Change 2014: Mitigation of Climate Change; Contribution of Working Group III to the Fifth Assessment Report of the Intergovernmental Panel on Climate Change; Cambridge University Press: Cambridge, UK; New York, NY, USA, 2014. 
5. Krey, V. Global energy-climate scenarios and models: A review. Wiley Interdiscip. Rev. Energy Environ. 2014, 3, 363-383. [CrossRef]

6. Mundaca, L.; Ürge-Vorsatz, D.; Wilson, C. Demand-side approaches for limiting global warming to $1.5^{\circ} \mathrm{C}$. Energy Effic. 2019, 12, 343-362. [CrossRef]

7. Vuuren, D.P.; van Hoogwijk, M.; Barker, T.; Riahi, K.; Boeters, S.; Chateau, J.; Scrieciu, S.; Van Vliet, J.; Masui, T.; Blok, K.; et al. Comparison of top-down and bottom-up estimates of sectoral and regional greenhouse gas emission reduction potentials. Energy Policy 2009, 37, 5125-5139. [CrossRef]

8. UNEP. Bridging the Emission Gap; United Nations Environment Programme: Nairobi, Kenya, 2011.

9. Akimoto, K.; Sano, F.; Homma, T.; Oda, J.; Nagashima, M.; Kii, M. Estimates of GHG emission reduction potential by country, sector, and cost. Energy Policy 2010, 38, 3384-3393. [CrossRef]

10. IPCC. Fourth Assessment Report of the Intergovernmental Panel on Climate Change; IPCC: Geneva, Switzerland, 2007.

11. McKinsey. Pathways to a Low-Carbon Economy-Version 2 of the Global Greenhouse Abatement Cost Curve; McKinsey \& Company: Brussels, Belgium, 2009.

12. Kesicki, F.; Ekins, P. Marginal abatement cost curves: A call for caution. Clim. Policy 2012, 12, $219-236$. [CrossRef]

13. IPCC. Climate Change 2014: Mitigation of Climate Change; IPCC: Geneva, Switzerland, 2014.

14. IEA. Energy Technology Perspectives 2017; International Energy Agency: Paris, France, 2017.

15. Wesselink, B.; Deng, Y. Sectoral Emission Reduction Potentials and Economic Costs for Climate Change; Ecofys: Utrecht, The Netherlands, 2009.

16. Lovins, A.B. Reinventing Fire; Chelsea Green Publishing: White River Junction, VT, USA, 2011.

17. UNEP. Profile of Emission Reduction Potentials in Developing Countries; UNEP Risø Centre: Roskilde, Denmark, 2013.

18. Xu, J.-H.; Fleiter, T.; Fan, Y.; Eichhammer, W. $\mathrm{CO}_{2}$ emission reduction potential in China's cement industry compared to IEA's Cement Technology Roadmap up to 2050. Appl. Energy 2014, 130, 592-602. [CrossRef]

19. Yuan, J.; Ng, S.H. Emission reduction measures ranking under uncertainty. Appl. Energy 2017, 188, $270-279$. [CrossRef]

20. Schallenberg-Rodríguez, J.; Notario-del Pino, J. Evaluation of on-shore wind techno-economic potential in regions and islands. Appl. Energy 2014, 124, 117-129. [CrossRef]

21. Olivier, J.G.J.; Peters, J.A.H.W. Trends in Global $\mathrm{CO}_{2}$ and Total Greenhouse Gas Emissions: Summary of the 2017 Report; PBL Netherlands Environmental Assessment Agency: The Hague, The Netherlands, 2017.

22. IEA. World Energy Outlook 2016; International Energy Agency: Paris, France, 2016.

23. IPCC. Climate Change 2001: Synthesis Report. A Contribution of Working Groups I, II, and III to the Third Assessment Report of the Intergovernmental Panel on Climate Change; Cambridge University Press: Cambrigde, UK; New York, NY, USA, 2001.

24. Blok, K.; Nieuwlaar, E. Introduction to Energy Analysis; Taylor \& Francis Ltd.: Oxfordshire, UK, 2016.

25. Squires, G.L. Practical Physics, 4th ed.; Cambridge University Press: Cambridge, UK, 2001; Section 4.1.

26. Blok, K. Improving Energy Efficiency by Five Percent and More per Year? J. Ind. Ecol. 2004, 8, 87-89. [CrossRef]

27. Van Ruijven, B.; Van Vuuren, D.P.; Boskaljon, W.; Neelis, M.; Saygin, M.P.D. Long-term model-based projections of energy use and $\mathrm{CO}_{2}$ emissions from the global steel and cement industries. Resour. Conserv. Recycl. 2016, 112, 15-36. [CrossRef]

28. Settele, J.; Scholes, R.; Betts, R.; Bunn, S.; Leadley, P.; Nepstad, D.; Overpeck, J.; Taboada, M. Terrestrial and Inland Water Systems. In Climate Change 2014: Impacts, Adaptation, and Vulnerability; Cambridge University Press: Cambridge, UK; New York, NY, USA, 2014.

29. PBL. IMAGE Baseline-Land-Use Emissions; PBL Netherlands Environmental Assessment Agency: The Hague, The Netherlands, 2017; unpublished.

30. Tanneberger, F.; Appulo, L. Peat for Speed. UNFCCC COP22 Marrakech; Wetlands International and Greifswald Germany-Greifswald Mire Centre: Wageningen, The Netherlands, 2016.

31. Miettinen, J.; Hooijer, A.; Vernimmen, R.; Chin Liew, S.; Page, S. From carbon sink to carbon source: Extensive peat oxidation in insular Southeast Asia since 1990. Environ. Res. Lett. 2017, 12, 024014. [CrossRef] 
32. Joosten, H.; Couwenberg, J.; Von Unger, M. International carbon policies as a new driver for peatland restoration. In Peatland Restoration and Ecosystem Services: Science, Policy and Practice; Bonn, A., Allott, T., Evans, M., Joosten, H., Stoneman, R., Eds.; Cambridge University Press/British Ecological Society: Cambridge, UK, 2016; pp. 291-313.

33. USEPA. Global Anthropogenic Non-CO2 Greenhouse Gas. Emissions: 1990-2030; Environmental Protection Agency: Washington, DC, USA, 2012.

34. Höglund-Isaksson, L. Global anthropogenic methane emissions 2005-2030. Atmos. Chem. Phys. 2012, 12, 9079-9096. [CrossRef]

35. Klimont, Z.; Höglund-Isaksson, L.; (IIASA, Laxenburg, Austria). Personal Communication, 2017.

36. Purohit, P.; Höglund-Isaksson, L. Global emissions of fluorinated greenhouse gases 2005-2050 with abatement potentials and costs. Atmos. Chem. Phys. 2017, 17, 2795-2816. [CrossRef]

37. Smith, P.; Martino, D.; Cai, Z.; Gwary, D.; Janzen, H.; Pushpam, K.; McCarl, B.; Ogle, S.; O’Mara, F.; Rice, C.; et al. Greenhouse gas mitigation in agriculture. Phil. Trans. R. Soc. B 2008, 363, 789-813. [CrossRef] [PubMed]

38. USEPA. Global Mitigation of Non-CO2 Greenhouse Gases: 2010-2030; Environmental Protection Agency: Washington, DC, USA, 2013.

39. Dimassi, B.; Mary, B.; Wylleman, R.; Labreuche, J.; Couture, D.; Piraux, F.; Cohan, J. Long-term effect of contrasted tillage and crop management on soil carbon dynamics during 41 years. Agric. Ecosyst. Environ. 2014, 64, 136-146. [CrossRef]

40. Bonn, A.; Reed, M.; Evans, C.; Joosten, H.; Bain, C.; Farmer, J.; Emmer, I.; Birnie, D. Investing in nature: Developing ecosystem service markets for peatland restoration. Ecosyst. Serv. 2014, 9, 54-65. [CrossRef]

41. World Bank. The Cost of Fire: An Economic Analysis of Indonesia's 2015 Fire Crisis; World Bank: Jakarta, Indonesia, 2016.

42. Wichtmann, W.; Schröder, C.; Joosten, H. Paludiculture-Productive Use of Wet Peatlands. Climate Protection—Biodiversity—Regional Economic Benefits; Schweizerbart Science Publishers: Stuttgart, Germany, 2016.

43. New Climate Economy Technical Note: Abatement Reduction Potential; The Global Commission on the Economy and Climat: London, UK, 2015. Available online: http://newclimateeconomy.report/workingpapers/wpcontent/uploads/sites/5/2016/04/NCE-technical-note-emission-reduction-potential_final.pdf (accessed on 24 October 2017).

44. Woolf, D.; Amonette, J.; Alayne Street-Perrott, F.; Lehmann, J.; Joseph, S. Sustainable biochar to mitigate global climate change. Nat. Commun. 2010, 1, 56. [CrossRef]

45. Pratt, K.; Moran, D. Evaluating the cost-effectiveness of global biochar mitigation potential. Biomass Bioenergy 2010, 34, 1149-1158. [CrossRef]

46. Stehfest, E.; Van den Berg, M.; Woltjer, G.; Westhoek, G. Options to reduce the environmental effects of livestock production-Comparison of two economic models. Agric. Syst. 2013, 26, 38-53. [CrossRef]

47. Nelleman, C.; MacDevette, M.; Manders, T.; Eickhout, B.; Svihus, B.; Prins, A. The Environmental Food Crisis -The Environment's Role in Averting Future Food Crises. A UNEP Rapid Response Assessment; United Nations Environmental Programme, GRID: Arendal, Norway, 2009.

48. Lundqvist, J. Losses and waste in the global crisis. Rev. Environ. Sci. Biotechnnol. 2009, 8, 121-123. [CrossRef]

49. Constructing the Future-Will the Building Sector Use Its Decarbonisation Tools? Climate Action Tracker, Utrecht/Cologne/Berlin. 2016. Available online: https://climateactiontracker.org/documents/47/CAT_201608-26_DecarbBuilding_CATAnalysis.pdf (accessed on 17 October 2017).

50. Blok, K.; Groenenberg, H.; Bardout, M.; Smeets, B. Quantification of the Mitigation Impact of the 2030 Recommendations; Ecofys: Utrecht, The Netherlands, 2015.

51. C40. Advancing Climate Ambition: Cities as Partners in Global Climate Action; C40: New York, NY, USA, 2014. Available online: http://c40-production-images.s3.amazonaws.com/researches/images/25_Advancing Climate_Ambition.original.pdf?1412878084 (accessed on 24 October 2017).

52. GBPN. What Is a Deep Renovation Definition? Global Building Performance Network: Paris, France, 2013. Available online: http://www.gbpn.org/sites/default/files/08.DR_TechRep.low_.pdf (accessed on 24 October 2017).

53. Schimschar, S.; Blok, K.; Boermans, T.; Hermelink, A. Germany's path towards nearly zero-energy buildings-Enabling the greenhouse gas mitigation potential in the building stock. Energy Policy 2011, 39, 3346-3360. [CrossRef] 
54. IRENA. Roadmap for a Renewable Energy Future; IRENA Innovation and Technology Centre: Bonn, Germany, 2016.

55. Wagner, N.; (IRENA, Bonn, Germany). Personal Communication, 2017.

56. Molenbroek, E.; Smith, M.; Surmeli, N.; Schimschär, S.; Waide, P.; Tait, J.; McAllister, C. Savings and Benefits of Global Regulations for Energy Efficient Products; European Commission: Brussels, Belgium, 2015.

57. CLASP. Opportunities for Success and CO2 Savings from Appliance Energy Efficiency Harmonisation; CLASP: Washington DC, USA, 2011. Available online: https://clasp.ngo/publications/opportunities-for-success-andco2-savings-from-appliance-energy-efficiency-harmonisation (accessed on 24 October 2017).

58. UNEP. Green Paper Policy Options to Accelerate the Global Transition to Advanced Lighting; United Nations Environment Programme: Nairobi, Kenya, 2014.

59. Bertoldi, P. Are current policies promoting a change in behaviour, conservation and sufficiency? An analysis of existing policies and recommendations for new and effective policies. In Proceedings of the ECEEE 2017 Summer Study on Energy Efficiency: Consumption, Efficiency and Limits; European Council for an Energy-Efficient Economy: Stockholm, Sweden, 2017.

60. Darby, S. The Effectiveness of Feedback on Energy Consumption; Environmental Change Institute, University of Oxford: Oxford, UK, 2006.

61. Ehrhardt-Martinez, K. A Comparison of Feedback-Induced Behaviors from Monthly Energy Reports, Online Feedback, and In-home Displays. In Proceedings ACEEE Summer Study on Energy Efficiency in Buildings; ACEEE: Washington, DC, USA, 2012.

62. Haegel, N.M.; Margolis, R.; Buonassisi, T.; Feldman, D.; Froitzheim, A.; Garabedian, R.; Green, M.; Glunz, S.; Henning, H.-M.; Holder, B.; et al. Terawat-scale photovoltaics: Trajectories and challenges. Science 2017, 356, 141-143. [CrossRef] [PubMed]

63. Creutzig, F.; Agoston, P.; Goldschmidt, J.; Luderer, G.; Nemet, G.; Pietzcker, R. The underestimated potential of solar energy to mitigate climate change. Nature Energy 2017, 2, 17140. [CrossRef]

64. Teske, S.; Sawyer, S.; Schäter, O.; Pregger, T.; Simon, S.; Naegler, T. Energy [R]evolution, a Sustainable World Energy Outlook 2015; Greenpeace International: Hamburg, Germany, 2015.

65. REN21. Renewables 2017-Global Status Report; Renewable Energy Policy Network for the 21st Century: Paris, France, 2017. Available online: http://www.ren21.net/status-of-renewables/global-status-report/ (accessed on 24 October 2017).

66. Breyer, C.; Bogdanov, D.; Gulagi, A.; Aghahosseini, A.; Barbosa, L.S.N.S.; Koskinen, O.; Barasa, M.; Caldera, U.; Afanasyeva, S.; Child, M.; et al. On the role of solar photovoltaics in global energy transition scenarios. Progress Photovolt. Res. Appl. 2017, 25, 727-745. [CrossRef]

67. Sitra. Green to Scale; Sitra Foundation: Helsinki, Finland, 2015. Available online: https://media.Sitra.fi/2017/ 02/28142523/Selvityksia105.pdf (accessed on 24 October 2017).

68. Afanador, A.; Begemann, E.; Bourgault, C.; Krabbe, O.; Wouters, K. The Potential of Scaling up Proven Low-Carbon Solutions; Ecofys: Utrecht, The Netherlands, 2015. Available online: https://media.Sitra.fi/2017/ 02/28142516/Ecofys_2015_potential_of_scaling_up-low_carbon_solutions.pdf (accessed on 19 October 2017).

69. GWEC. Global Wind Report 2016; Global Wind Energy Council: Brussels, Belgium, 2016. Available online: http://gwec.net/publications/global-wind-report-2/global-wind-report-2016/ (accessed on 24 October 2017).

70. Mac Dowell, N.; Fajardy, M. Inefficient power generation as an optimal route to negative emissions via BECCS? Environ. Res. Lett. 2017, 12, 045004. [CrossRef]

71. Herzog, H.; Smekens, K.; Dadhich, P.; Dooley, J.; Fujii, Y.; Hohmeyer, O.; Riahi, K. Costs and Economic Potential. In IPCC Special Report on Carbon Dioxide Capture and Storage; Cambridge University Press: Cambridge, UK; New York, NY, USA, 2005.

72. Arasto, A.; Onarheim, K.; Tsupari, E.; Kärki, J. Bio-CCS: Feasibility comparison of large scale carbon-negative solution. Energy Procedia 2014, 63, 6756-6769. [CrossRef]

73. McGlashan, N.; Workman, M.; Caldecott, B.; Shah, N. Negative Emissions Technologies; Grantham Institute for Climate Change and the Environment: London, UK, 2012; Briefing Paper No 8.

74. Johnson, N.; Parker, N.; Ogden, J. How negative can biofuels with CCS take us and at what cost? Energy Procedia 2014, 63, 6770-6791. [CrossRef]

75. Deng, Y.; Blok, K.; Van der Leun, K. Transition to a fully sustainable global energy system. Energy Strategy Rev. 2012, 1, 109-121. [CrossRef] 
76. Messinger, J.; DeWitt, S. Bonn Challenge on Track to Meet Land Restoration Goal by 2020; World Resources Institute: Washington, DC, USA, 2015. Available online: http://www.wri.org/blog/2015/03/bonn-challengetrack-meet-land-restoration-goal-2020-0 (accessed on 24 October 2017).

77. Verdone, M.; Olsen, N.; Wylie, P.; Saint Laurent, C.; Maginnis, M. Making the Case for Forest Landscape Restoration. White Paper, Initial Working Draft for Future Discussion. Post-Bonn Challenge 2.0 Ministerial Event, 20-21 March 2015; IUCN: Gland, Switzerland, 2015.

78. Akbar, S.; Kleiman, G.; Menon, S.; Segafredo, L. Climate-Smart Development: Adding up the Benefits of Actions that Help Build Prosperity, End Poverty and Combat Climate Change: Main Report; World Bank Group: Washington, DC, USA, 2014. Available online: http://documents.worldbank.org/curated/en/794281468155721244/Main-report (accessed on 10 October 2017).

79. Worell, E.; Carreon, J.R. Energy demand for materials in an international context. Philos. Trans. R. Soc. A 2017, 375, 20160377. [CrossRef]

80. Saygin, D.; Worrell, E.; Patel, M.K.; Gielen, D.J. Benchmarking the energy use of energy-intensive industries in industrialized and in developing countries. Energy 2011, 36, 6661-6673. [CrossRef]

81. Ecofys and Circle Economy. Inplementing Circular Economy Globally Makes Paris Targets Achievable; Ecofys: Utrecht, The Netherlands, 2016.

82. ICCT. Global Transportation Energy and Climate Roadmap; The International Council on Clean Transportation: Washington, DC, USA, 2012. Available online: http://www.theicct.org/publications/global-transportationenergy-and-climate-roadmap (accessed on 24 October 2017).

83. Bloomberg New Energy Finance. Long-Term Electric Vehicle Outlook 2018; Bloomberg NEF: New York, NY, USA, 2018.

84. Mason, J.; Fulton, L.; McDonald, Z. A Global High Shift Cycling Scenario: The Potential for Dramatically Increasing Bicycle and E-Bike Use in Cities around the World, with Estimated Energy, CO2, and Cost Impacts; Institute for Transportation \& Development Policy: New York, NY, USA, 2015.

85. ICAO. Environmental Report 2013; International Civil Aviation Organisation: Montreal, QC, Canada, 2013. Available online: http://fapp.icao.int/Environmental-Report-2013/files/assets/basic-html/index.html\#1 (accessed on 24 October 2017).

86. Alvik, S.; Eide, M.; Endresen, Ø.; Hoffman, P.; Longva, T. Pathways to Low Carbon Shipping-Abatement Potential Towards 2030; DNV Det Norske Veritas: Oslo, Norway, 2010.

87. Faber, J.; Wang, H.; Nelissen, D.; Russell, B.; Amand, D. Marginal Abatement Costs and Cost Effectiveness of Energy-Efficiency Measures; Institute of Marine Engineering, Science and Technology: London, UK, 2011.

88. Eide, M.; Longva, T.; Hoffmann, P.; Endresen, Ø.; Dalsøren, S. Future cost scenarios for reduction of ship $\mathrm{CO}_{2}$ emissions. Marit. Policy Manag. 2011, 38, 11-37. [CrossRef]

89. Hoffmann, P.; Eide, M.; Endresen, Ø. Effect of proposed $\mathrm{CO}_{2}$ emission reduction scenarios on capital expenditure. Marit. Policy Manag. 2012, 39, 443-460. [CrossRef]

90. Bouman, E.; Lindstad, E.; Rialland, A.; Stromann, A. State-of-the-art technologies, measures, and potential for reducing GHG emissions from shipping-A review. Transp. Res. Part D 2017, 52, 408-421. [CrossRef]

91. Raising Ambition to Reduce International Aviation and Maritime Emissions. Contributing Paper for Seizing the Global Opportunity: Partnerships for Better Growth and a Better Climate; New Climate Economy: London, UK; Washington, DC, USA, 2015. Available online: http://newclimateeconomy.report/misc/working-papers (accessed on 24 October 2017).

92. BLE. Evaluations und Erfahrungsbericht für das Jahr 2015, Biomassestrom-Nachhaltigkeitsverordnung and Biokraftstoff-Nachhaltigkeitsverordnung; Bundesanstalt für Landwirtschaft und Ernährung: Bonn, Germany, 2016.

93. Renforth, P. The potential of enhanced weathering in the UK. Int. J. Greenh. Gas Control 2012, 10, $229-243$. [CrossRef]

94. Renforth, P.; Washbourne, C.; Taylder, J.; Manning, D. Silicate Production and Availability for Mineral Carbonation. Environ. Sci. Technol. 2011, 10, 2035-2041. [CrossRef] [PubMed]

95. McLaren, D. A comparative global assessment of potential negative emissions technologies. Process. Saf. Environ. Prot. 2012, 90, 489-500. [CrossRef]

96. UNEP. Emission Gap Report 2017; United Nations Environment Programme (UNEP): Nairobi, Kenya, 2017.

97. IEA. Market. Report Series: Energy Efficiency 2018; International Energy Agency: Paris, France, 2018. 
98. Lazard. Levelized Cost of Energy Analysis 10.0; Lazard: New York, NY, USA, 2016. Available online: https://www.lazard.com/media/438038/levelized-cost-of-energy-v100.pdf (accessed on 24 October 2017).

99. Lovins, A.B. How big is the energy efficiency resource? Environ. Res. Lett. 2018, 13, 090401. [CrossRef]

100. Grübler, A.; Wilson, C.; Bento, N.; Boza-Kiss, B.; Krey, V.; McCollum, D.L.; Rao, N.D.; Riahi, K.; Rogelj, J.; De Stercke, S.; et al. A low energy demand scenario for meeting the $1.5^{\circ} \mathrm{C}$ target and sustainable development goals without negative emissions technologies. Nat. Energy 2018, 3, 515-527. [CrossRef]

101. Griscom, B.W.; Adams, J.; Ellis, P.W.; Houghton, R.A.; Lomax, G.; Miteva, D.A.; Schlesinger, W.H.; Shoch, D.; Siikamäki, J.V.; Smith, P.; et al. Natural Climate Solutions. Proc. Natl. Acad. USA 2017, 114, 11645-11650. [CrossRef]

102. IRENA. Renewable Energy Auctions: Analysing 2016; IRENA: Abu Dhabi, UAE, 2017. Available online: http://www.irena.org/DocumentDownloads/Publications/IRENA_REAuctions_summary_2017.pdf (accessed on 10 October 2017).

103. ICCT. Technology Uptake, Costs, and Benefits under a Next-Phase Passenger Car Efficiency Program in Brazil; ICCT: Washington, DC, USA, 2017. Available online: http://www.theicct.org/publications/technology-uptake-costsandbenefits-under-next-phase-passenger-car-efficiency-program (accessed on 24 October 2017).

104. UNEP. Emission Gap Report 2016; United Nations Environment Programme (UNEP): Nairobi, Kenya, 2016.

105. Chen, X.; Luo, Y.; Zhou, Y.; Lu, M. Carbon Sequestration Potential in Stands under the Grain for Green Program in Southwest China. PLoS ONE 2016, 11, e0150992. [CrossRef]

106. Kim, K.; Zsuffa, L. Reforestation of South Korea: The history and analysis of a unique case in forest tree improvement and forestry. For. Chron. 1994, 70, 58-64. [CrossRef]

107. Riahi, K.; van Vuuren, D.P.; Kriegler, E.; Edmonds, J.; O’Neill, B.C.; Fujimori, S.; Bauer, N.; Calvin, K.; Dellink, R.; Fricko, O.; et al. The Shared Socioeconomic Pathways and their energy, land use, and greenhouse gas emissions implications: An overview. Glob. Environ. Chang. 2017, 42, 153-168. [CrossRef]

108. Tavoni, M.; Kriegler, E.; Riahi, K.; Van Vuuren, D.P.; Aboumahboub, T.; Bowen, A.; Calvin, K.; Campiglio, E.; Kober, T.; Jewell, J.; et al. Post-2020 climate agreements in the major economies assessed in the light of global models. Nat. Clim. Chang. 2015, 5, 119-126. [CrossRef]

109. Edelenbosch, O.Y.; Van Vuuren, D.P.; Blok, K.; Calvin, K.; Fujimori, S. Mitigating energy demand emissions: The integrated modelling perspective. Appl. Energy 2020, 261, 114347. [CrossRef] 